Article

\title{
Topaz, a Potential Volatile-Carrier in Cold Subduction Zone: Constraint from Synchrotron X-ray Diffraction and Raman Spectroscopy at High Temperature and High Pressure
}

\author{
Shijie Huang ${ }^{1,2}$, Jingui Xu ${ }^{3}$, Chunfa Chen ${ }^{4}$, Bo Li ${ }^{1,2}$, Zhilin Ye ${ }^{1,2}$, Wei Chen ${ }^{1,2,5}$, \\ Yunqian Kuang ${ }^{1,2,6}$, Dawei Fan ${ }^{1}$, Wenge Zhou ${ }^{1, *}$ and Maining Ma ${ }^{7, *}$ \\ 1 Key Laboratory of High-Temperature and High-Pressure Laboratory for High Temperature and High \\ Pressure Study of the Earth's Interior, Institute of Geochemistry, Chinese Academy of Sciences, \\ Guiyang 550002, China; roberthuang1996@126.com (S.H.); libo@mail.gyig.ac.cn (B.L.); \\ yezhilin@mail.gyig.ac.cn (Z.Y.); chen123wei2016@126.com (W.C.); kuangyunqian@126.com (Y.K.); \\ fandawei@mail.gyig.ac.cn (D.F.) \\ 2 College of Earth and Planetary Sciences, University of Chinese Academy of Sciences, Beijing 100049, China \\ 3 Hawai'i Institute of Geophysics and Planetology, School of Ocean and Earth Science and Technology, \\ University of Hawai'i at Manoa, Honolulu, HI 96822, USA; xujingui1990@126.com \\ 4 Zhejiang Geological Prospecting Institute of China Chemical Geology and Mine Bureau, \\ Hangzhou 310002, China; france319@126.com \\ 5 Guizhou Polytechnic of Construction, Guiyang 551400, China \\ 6 Bureau of natural resources and planning of Yongzhou, Yongzhou 425000, China \\ 7 Key Laboratory of Computational Geodynamics, College of Earth and Planetary Sciences, \\ University of Chinese Academy of Sciences, Beijing 100049, China \\ * Correspondence: zhouwenge@vip.gyig.ac.cn (W.Z.); mamn@ucas.ac.cn (M.M.)
}

Received: 31 July 2020; Accepted: 1 September 2020; Published: 3 September 2020

\begin{abstract}
The equation of state and stability of topaz at high-pressure/high-temperature conditions have been investigated by in situ synchrotron X-ray diffraction (XRD) and Raman spectroscopy in this study. No phase transition occurs on topaz over the experimental pressure-temperature $(P-T)$ range. The pressure-volume data were fitted by the third-order Birch-Murnaghan equation of state (EoS) with the zero-pressure unit-cell volume $V_{0}=343.86$ (9) $\AA^{3}$, the zero-pressure bulk modulus $K_{0}=172$ (3) GPa, and its pressure derivative $K_{0}^{\prime}=1.3(4)$, while the obtained $K_{0}=155$ (2) GPa when fixed $K^{\prime}{ }_{0}=4$. In the pressure range of $0-24.4 \mathrm{GPa}$, the vibration modes of in-plane bending $\mathrm{OH}$-groups for topaz show non-linear changes with the increase in pressure, while the other vibration modes show linear changes. Moreover, the temperature-volume data were fitted by Fei's thermal equation with the thermal expansion coefficient $\alpha_{300}=1.9(1) \times 10^{-5} \mathrm{~K}^{-1}$ at $300 \mathrm{~K}$. Finally, the $P$-T stability of topaz was studied by a synchrotron-based single-crystal $X R D$ at simultaneously high $P$ - $T$ conditions up to $10.9 \mathrm{GPa}$ and $700 \mathrm{~K}$, which shows that topaz may maintain a metastable state at depths above $370 \mathrm{~km}$ in the upper mantle along the coldest subducting slab geotherm. Thus, topaz may be a potential volatile-carrier in the cold subduction zone. It can carry hydrogen and fluorine elements into the deep upper mantle and further affect the geochemical behavior of the upper mantle.
\end{abstract}

Keywords: topaz; high temperature; high pressure; Synchrotron X-ray diffraction; Raman spectroscopy

\section{Introduction}

Plate subduction is an important way to carry water into the deep Earth, and hydrous minerals in subduction zones are important carriers of water into the Earth's interior [1-4]. With the increase in 
subduction depth, hydrous minerals will dehydrate, and the produced fluids will react with mantle wall-rocks inducing their melting to form arc magma in subduction zones [5]. This process has a significant influence on the physical and chemical properties of the Earth's mantle $[2,5,6]$. Furthermore, the dehydration occurs in the crust and the subducting lithosphere of the deep mantle, and it is mainly dependent on the stability of hydrous minerals in subduction zones [7-10]. Therefore, the structural stability and thermoelastic properties of hydrous minerals at high-pressure and high-temperature (high $P-T)$ conditions are the keys to understanding the geodynamic processes in subduction zones [10-16].

Topaz has a wide $P-T$ stability field, at least up to $12 \mathrm{GPa}$ and $\sim 1100{ }^{\circ} \mathrm{C}$ [17]. The synthesis experiment showed that topaz-OH breaks down to kyanite $+\mathrm{H}_{2} \mathrm{O}$ above $1023 \mathrm{~K}$ at $6 \mathrm{GPa}$ [18]. A previous study even indicated that topaz can be subducted to a depth of $1400 \mathrm{~km}$ under the cold subduction conditions, showing a metastable state under very high pressures [19]. As an important hydrous aluminosilicate mineral, topaz is widely found in granitoids and metamorphic sedimentary rock. Some studies have shown that topaz in subduction zones can carry water and fluorine to a depth of more than $150 \mathrm{~km} \mathrm{[17,20-22].} \mathrm{Moreover,} \mathrm{the} \mathrm{occurrence} \mathrm{of} \mathrm{ultrahigh-pressure} \mathrm{(UHP)}$ metamorphic assemblages in the collisional orogenic belts suggests that continent crust subduction might reach depths of 200-300 km [17,19,22,23]. For example, granitoid subduction can be seen in the western Pacific region, through tectonic erosion, arc subduction, and sediment-trapped subduction [20]. The content of topaz in granitoids is up to 3-5\% [24]. Granitoids account for more than $45 \%$ of the upper part of the continental crust [21]. Therefore, topaz might reach depths of 200-300 km with the continent crust subduction. In the Earth's interior, topaz does not experience low-temperature transition, and the major transformations undergone by topaz are likely to be either dehydration or conversion to high-pressure hydrous aluminous phases $[19,23,25]$. Thus, topaz is an important carrier of water and fluorine components from the subducting plate into the deep mantle, especially at the cold subducted slabs.

Topaz with a chemical formula of $\mathrm{Al}_{2}\left[\mathrm{SiO}_{4}\right](\mathrm{F}, \mathrm{OH})_{2}$ is an important aluminosilicate mineral containing water and fluorine. Furthermore, fluorine-bearing topaz mainly occurs in fluorine-rich pegmatite, while the hydroxyl topaz group mainly occurs in ultra-high-pressure metamorphic rocks [26]. The proportion of $\mathrm{F}$ and $\mathrm{OH}$ in topaz is above $20 \mathrm{wt} . \%$, while the molar ratio of $\mathrm{OH}$ in $\mathrm{OH}$ and $\mathrm{F}\left(\mathrm{X}_{\mathrm{OH}}\right.$ $=\mathrm{OH} /(\mathrm{OH}+\mathrm{F}))$ is generally less than 0.5 [27-30]. Consequently, the maximum $\mathrm{OH}$ content of topaz is about $10 \mathrm{wt} . \%$. Therefore, topaz contains much more water than nominally anhydrous minerals.

Topaz belongs to the orthorhombic crystal system with a space group of Pbnm. In the crystal structure of topaz (Figure 1), $\mathrm{Si}^{4+}$ occupies isolated tetrahedral $\left[\mathrm{SiO}_{4}\right]$ sites, while $\mathrm{Al}^{3+}$ occupies the space of octahedron to form $\left[\mathrm{AlO}_{6}\right] /\left[\mathrm{AlO}_{4} \mathrm{~F}_{2}\right]$ octahedron, and the tetrahedron is connected by a curved chain to a pair of $\left[\mathrm{AlO}_{6}\right] /\left[\mathrm{AlO}_{4} \mathrm{~F}_{2}\right]$ octahedrons [31]. All four corner tops of each $\left[\mathrm{SiO}_{4}\right]$ tetrahedron are connected with adjacent $\left[\mathrm{SiO}_{4}\right]$ tetrahedrons and $\left[\mathrm{AlO}_{6}\right]^{-}$octahedrons to form a framework silicate structure. $\mathrm{O}^{2-}$ in the $\left[\mathrm{AlO}_{6}\right]^{-}$octahedron has some residual charge, and the gap between tetrahedron and octahedron in the frame structure is large, which is easy to absorb $\mathrm{F}^{-}$and $\mathrm{H}^{+}$anions (Figure 1a). Along the $b$ axis (010) (Figure $1 \mathrm{~b}$ ), the crystal is stacked in the manner of "ABAB".

At present, there are many studies, including experiments and theoretical calculations, about the equation of state (EoS) on topaz, where the highest pressure condition is $60 \mathrm{GPa}[19,30,32-34]$. However, the experimental results are not completely consistent. Gatta et al. conducted a single-crystal X-ray diffraction (XRD) study of topaz with composition $\mathrm{Al}_{2.00} \mathrm{Si}_{1.05} \mathrm{O}_{4.00}\left(\mathrm{OH}_{0.26} \mathrm{~F}_{1.75}\right)$ up to $10.55 \mathrm{GPa}$ and obtained $K_{0}=164$ (2) GPa [30]. Similarly, Komatsu et al. (2003) obtained $K_{0}=154$ (2) GPa of topaz with composition $\mathrm{Al}_{2.01} \mathrm{SiO}_{4} \mathrm{~F}_{1.57}(\mathrm{OH})_{0.43}$, which is $6 \%$ lower than that of Gatta et al. [30,34]. Furthermore, Komatsu et al. (2008) obtained $K_{0}=145$ (4) $\mathrm{GPa}$ of topaz with composition $\mathrm{Al}_{2} \mathrm{SiO}_{4}\left(\mathrm{OD}_{1.45}\right.$, $\left.\mathrm{OH}_{0.55}\right)_{\Sigma 2.0}$ using neutron powder diffraction method, which is $12 \%$ lower than that of Gatta et al. [33]. In addition, there are also some theoretical calculation studies about the EoS of topaz. Mookherjee et al. investigated the $K_{0}$ of topaz with composition $\mathrm{Al}_{2} \mathrm{SiO}_{4}(\mathrm{OH})_{2}$ by first principles simulation and obtained $K_{0}=166.4$ (6) GPa, while Ulian et al. calculated the $K_{0}$ of topaz with composition $\mathrm{Al}_{2} \mathrm{SiO}_{4} \mathrm{~F}(\mathrm{OH})$ by quantum mechanical approach and obtained $K_{0}=165$ (3) GPa $[35,36]$. The theoretical calculation 
results of topaz with different composition $\left(\mathrm{Al}_{2} \mathrm{SiO}_{4}(\mathrm{OH})_{2}\right.$ vs. $\left.\mathrm{Al}_{2} \mathrm{SiO}_{4} \mathrm{~F}(\mathrm{OH})\right)$ are very similar with each other $\left(K_{0}=166.4\right.$ (6) GPa vs. $K_{0}=165$ (3) GPa), which is clearly different from the experimental results. Thus, there is still a great controversy on the EoS parameters of topaz.
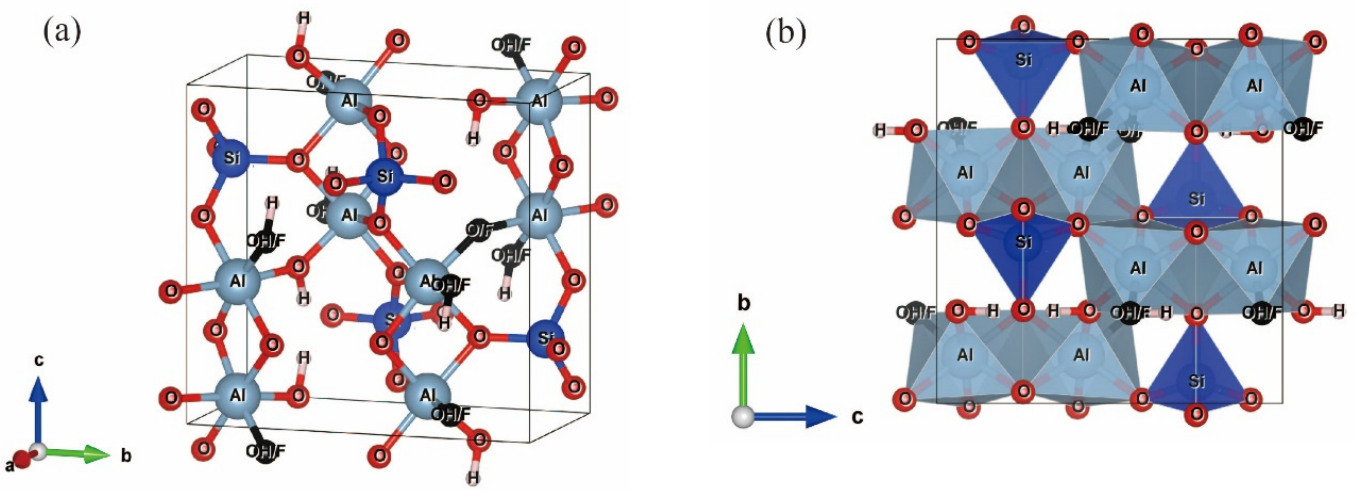

Figure 1. Crystal structure of topaz at ambient conditions with the style of ball-and-stick (a) and the style of polyhedron (b). Light blue for aluminum, dark blue for silicon, red for oxygen, light red for hydrogen, and black for fluorine instead of oxygen or hydroxide. The crystal structure data are obtained from Gatta et al. (2006) [30].

Furthermore, there are only two previous studies on the thermal expansion of topaz at high temperatures [34,37]. The highest experimental temperature in these two studies was $1173 \mathrm{~K}$ finished by Komatsu et al. using the powder XRD method [34]. However, there were only six data points in the temperature range up to $1173 \mathrm{~K}$, which may seriously affect the fitting accuracy of the thermal expansion coefficient. Therefore, the thermal expansion of topaz needs to be further investigated.

Additionally, the high $P$-T stable field of topaz in different chemical systems has been investigated extensively. Wunder et al. [22] studied the paragenetic mineral assemblage in the $\mathrm{Al}_{2} \mathrm{O}_{3}-\mathrm{SiO}_{2}-\mathrm{H}_{2} \mathrm{O}$ system at 5-10 GPa and up to $1273 \mathrm{~K}$. Their result indicated that topaz with a composition close to $\mathrm{Al}_{2} \mathrm{SiO}_{4}(\mathrm{OH})_{2}$ is stable in the P-T field of 700-1000 K and 5.5-10 GPa. Subsequently, Ono et al. [23] carried out a similar experiment and found that topaz can be stable up to $1800 \mathrm{~K}$ and $13 \mathrm{GPa}$. On the other hand, the results of single-crystal/powder XRD, neutron powder diffraction, and luminescence spectroscopy of $\mathrm{Cr}^{3+}$ implied that topaz is metastable up to $1173 \mathrm{~K}$ at atmospheric pressure and up $60 \mathrm{GPa}$ at room temperature [19,30,32-36,38]. For example, Komatsu et al. [34] found that the metastable temperature of topaz was $1173 \mathrm{~K}$ at atmosphere pressure by powder XRD experiment, while Gatta et al. [32] found that the metastable pressure of topaz was $45 \mathrm{GPa}$ at room temperature by single-crystal XRD experiment. Recently, O'Bannon and Williams [19] found that topaz can exist in the form of metastable state at $60 \mathrm{GPa}$ by luminescence spectroscopy.

The above previous studies have addressed, to some extent, the $P$ - $T$ stable field of topaz in the hot subduction zone. However, the stability of topaz under relatively low-temperature and high-pressure conditions in the cold subduction zone remains unclear. This will hinder our correct understanding of the water circulation and dynamic process in the cold subduction zone.

Based on the above discussion, the EoS, thermal expansion, and stability of a natural topaz were studied using the synchrotron single-crystal XRD under high temperature and pressure in this study. Apart from the single-crystal XRD, Raman spectroscopy was also used to judge the structural stability of topaz at high-pressure conditions. Finally, the $P-T$ phase diagram and stability of topaz and its effect on water and fluorine migration in the subduction zone, especially in the cold subducting zone, are further discussed.

\section{Sample and Experiments}

\subsection{Sample}

A natural topaz crystal selected in this study was collected from Brazil. It was colorless, transparent, and columnar, and had good crystal morphology. The chemical composition of the topaz sample was 
determined by JXA-8230 electron microprobe (JEOL, Akishima-shi, Japan) with the accelerating voltage of $15 \mathrm{kV}$, a beam current of $20 \mathrm{nA}$, and a beam diameter of $5 \mu \mathrm{m}$. And then the chemical formula was estimated as $\mathrm{Al}_{1.935 \pm 0.011}\left[\left(\mathrm{Si}_{0.935 \pm 0.011} \mathrm{Al}_{0.065 \pm 0.011}\right) \mathrm{O}_{4.000}\right]\left(\mathrm{OH}_{0.408 \pm 0.021} \mathrm{~F}_{1.592 \pm 0.021}\right)$.

\subsection{Synchrotron Single-Crystal XRD Experiments}

In situ Synchrotron single-crystal XRD experiments contain two-types of experiments; one was conducted at high-pressure and ambient-temperature conditions, while the other was carried out under simultaneous high-pressure and high-temperature conditions.

\subsubsection{High-Pressure and Ambient-Temperature Single-Crystal XRD Experiment}

A short symmetrical diamond anvil cell (DAC) containing a pair of diamond anvils (500 $\mu$ m culets) was used for the high-pressure measurements up to 13.4 GPa. A rhenium gasket pre-indented to a thickness of $\sim 65 \mu \mathrm{m}$ with a hole of $300 \mu \mathrm{m}$ in diameter was used as the sample chamber. One piece of the single-crystal topaz sample, together with Au powder, which was used as the pressure calibrator [39], were loaded into the sample chamber. XRD patterns of Au were collected at each pressure before and after sample data collection, and the average pressure value was taken. Neon gas was used as the pressure medium by the gas-loading system at the GeoSoilEnviroConsortium for Advanced Radiation Sources (GSECARS) of the Advanced Photon Source (APS), Argonne National Laboratory (ANL) [40].

Synchrotron single-crystal XRD experiments under high-pressure and ambient-temperature conditions were carried out at the 13-BM-D experimental station of GSECARS, APS. The wavelength of the incident $X$-ray beam was $0.3344 \AA$, and the beam size was $3 \times 7 \mu \mathrm{m}^{2}$. Data were collected rotating the DAC for $30^{\circ}$ around the vertical axis of the instrument ( $\omega$-axis, from $-15^{\circ}$ to $\left.+15^{\circ}\right)$, with a typical exposure time of $2 \mathrm{~s} / \mathrm{deg}$. The GSE_ADA software package was used to analyze all the diffraction images. The unit-cell parameters of topaz at high pressure (Table 1) were further re-calibrated by RSV software [41].

Table 1. The unit-cell parameters of topaz at high pressures.

\begin{tabular}{ccccc}
\hline Pressure (GPa) & $\boldsymbol{a}(\mathbf{\AA})$ & $\boldsymbol{b}(\mathbf{A})$ & $\boldsymbol{c}(\AA)$ & $\boldsymbol{V}\left(\AA^{3}\right)$ \\
\hline $0.26(1)$ & $4.6463(7)$ & $8.801(1)$ & $8.394(1)$ & $343.25(7)$ \\
$0.59(2)$ & $4.6421(7)$ & $8.799(1)$ & $8.391(1)$ & $342.72(6)$ \\
$1.23(5)$ & $4.6382(6)$ & $8.785(1)$ & $8.379(1)$ & $341.40(7)$ \\
$3.8(2)$ & $4.6105(6)$ & $8.758(1)$ & $8.331(3)$ & $336.4(1)$ \\
$4.6(2)$ & $4.6034(5)$ & $8.7467(9)$ & $8.320(1)$ & $334.99(6)$ \\
$5.5(2)$ & $4.5959(5)$ & $8.7321(9)$ & $8.305(1)$ & $333.30(6)$ \\
$6.7(3)$ & $4.5828(5)$ & $8.7219(9)$ & $8.280(1)$ & $330.96(6)$ \\
$7.6(3)$ & $4.5752(5)$ & $8.7083(9)$ & $8.270(1)$ & $329.49(6)$ \\
$8.6(3)$ & $4.5653(5)$ & $8.6955(9)$ & $8.251(1)$ & $327.56(6)$ \\
$9.9(4)$ & $4.5521(5)$ & $8.6787(9)$ & $8.227(1)$ & $325.01(6)$ \\
$11.2(5)$ & $4.5407(5)$ & $8.6639(9)$ & $8.204(1)$ & $322.73(6)$ \\
$13.4(5)$ & $4.5219(5)$ & $8.6381(9)$ & $8.171(1)$ & $319.15(6)$ \\
\hline
\end{tabular}

The numbers in parentheses represent the error; for example, 0.26 (1) means $0.26 \pm 0.01$.

\subsubsection{High-Pressure and High-Temperature Single-Crystal XRD Experiment}

A BX90-type external-heating DAC (EHDAC, Beijing Scistar Technology Co. Ltd., Beijing, China) [42] was used for the simultaneous high-pressure and high-temperature measurements up to 10.9 GPa and $700 \mathrm{~K}$. A rhenium foil was placed between a pair of diamond anvils as a gasket with an original thickness of about $250 \mu \mathrm{m}$. A K-type thermocouple was used for the high-temperature measurements of the sample chamber in the EHDAC. The thermocouple was attached to one of the diamond surfaces approximately $500 \mu \mathrm{m}$ away from its culet and clad with a ceramic adhesive (Resbond 920) [43], which was thermally conductive and electrically insulating. A single-crystal platelet was then placed into the sample chamber, together with gold $(\mathrm{Au})$ powder as the pressure calibrant for the XRD 
experiments [39] as well as a few ruby spheres as pressure indicators for the neon gas-loading [44]. The neon pressure medium was loaded into the sample chamber using the GSECARS gas-loading system [40]. After neon gas loading, the sample chamber was reduced from $\sim 300 \mu \mathrm{m}$ to $\sim 180 \mu \mathrm{m}$, and the initial pressure was about $0.33 \mathrm{GPa}$. At each $P$ - $T$ point, the diffraction patterns of $A u$ were collected before and after the sample diffraction data collected, and the pressure change no more than $\pm 0.1 \mathrm{GPa}$. Temperatures of the sample chamber were actively stabilized within $\pm 1 \mathrm{~K}$ using the temperature-power feedback program with a remotely controlled.

The synchrotron single-crystal XRD experiment under high-pressure and high-temperature conditions was carried out at 13-BM-C experimental station of the GSECARS, APS. The wavelength of the incident $X$-ray beam was $0.4335 \AA$, and the beam size was $15 \times 20 \mu \mathrm{m}^{2}$. We used a MAR165 CCD detector (Rayonix, L.L.C, Evanston, IL, USA) to collect the diffraction images, and LaB6 powder was used as the diffraction standard [45]. Wide and stepped $\varphi$ exposures were collected for each single-crystal sample at each $P$ - $T$ point with a typical exposure time of $3 \mathrm{~s} / \mathrm{deg}$. The APEX3 software package (DOC-M86-EXX229 V1, Bruker AXS Inc., Madison, WI, USA) was used to analyze all the diffraction images.

\subsection{High-Temperature Synchrotron Powder XRD Experiment}

A modified Merrill-Bassett type DAC with a pair of $400 \mu \mathrm{m}$ culet-size diamond anvil was used for high-temperature powder XRD experiment up to $713 \mathrm{~K}$. The T301 stainless steel foil was used for gasket, which was pre-indented to a thickness of $\sim 100 \mu \mathrm{m}$ and then drilled to a diameter of $300 \mu \mathrm{m}$, served as the sample chamber. The topaz sample powders were slightly pressed between two opposing diamond anvils to form an approximately $80 \mu \mathrm{m}$ thick disk, and a piece of topaz sample about $250 \mu \mathrm{m}$ in diameter was loaded into the sample chamber without any pressure medium. Heating was carried out using a resistance-heating system, and the temperature was measured by the K-type thermocouple, which was attached to the pavilion of the diamond. Each in situ XRD pattern was collected after heating, and the spectra were selected after the experiment temperature was kept for $600 \mathrm{~s}$. The typical exposure time for collecting diffraction patterns of the topaz sample was $300 \mathrm{~s}$. Details of the experimental setup and cell assembly were described in Fan et al. (2010) [46].

The in situ powder XRD experiment at high temperature up to $713 \mathrm{~K}$ was completed at the $4 \mathrm{~W} 2$ beamline of the Beijing Synchrotron Radiation Facility (BSRF). The wavelength of the monochromatic incident X-ray beam was $0.6199 \AA$, and the beam size was $20 \times 30 \mu \mathrm{m}^{2}$. $\mathrm{CeO}_{2}$ was adopted as the diffraction standard. The sample-detector distance was calculated from the powder $\mathrm{CeO}_{2}$ diffraction pattern at ambient conditions. XRD patterns were collected by an image plate detector (MAR-345, MarXperts, Norderstedt, Germany). The diffraction patterns were integrated to generate the conventional one-dimensional profiles using the Fit2D program (1987-2001 Andy Hammersley, European Synchrotron Radiation Facility, Grenoble, France [47]). Analysis of all the patterns was carried out by means of the full profile-fitting technique implemented in the EXPGUI/GSAS software package (1.80 (readexp.tcl 1.46), Los Alamos National Laboratory, Los Alamos, NM, USA) [48,49]. Refinement of peak positions and extraction of cell parameters were achieved by reducing full diffraction patterns following the Le Bail method [50]. The unit-cell volumes of topaz were estimated from the full spectrum fitting (Le Bail refinement) of XRD profiles.

\subsection{High-Pressure Raman Spectroscopy Experiment}

A symmetrical DAC containing a pair of diamonds with $500 \mu \mathrm{m}$ culets was used for the high-pressure Raman spectroscopy measurements up to $24.4 \mathrm{GPa}$. A stainless steel foil (type T301) gasket was pre-indented to a thickness of $\sim 65 \mu \mathrm{m}$, and then a hole was drilled in the center with a diameter of $300 \mu \mathrm{m}$ used as the sample chamber. One piece of the single-crystal topaz sample, together with one ruby chip (as the pressure calibrant), was loaded in the sample chamber. The neon pressure medium was loaded into the sample chamber using the gas-loading system at the GSECARS of the APS, ANL [40]. The fluorescence spectra of ruby were collected before and after each data collection, 
and the positions of R1 and R2 peaks were determined by Lorentzian function fitting. The pressure was calculated from the fitted R1 and R2 peak positions using the method of Mao et al. (1986) [44]. Raman spectra were collected with the Renishaw InVia spectrometer equipped with a Peltier-cooled charge-coupled device (CCD) detector. The sample was excited with a $532 \mathrm{~nm}$ wavelength laser. The laser light was focused using a Leica microscope with a long-distance $20 \times$ objective to a beam size of about $2 \mu \mathrm{m}$ diameter with the laser powder being $2 \mathrm{~mW}$ on the sample. The laser heating effect should not occur under these conditions. The wavenumber of Raman displacement was calibrated with a single crystal silicon. Each Raman spectrum was collected with a total exposure time of $300 \mathrm{~s}$, and Raman spectra of 100 1200 $\mathrm{cm}^{-1}$ were measured. Raman peaks were fitted to obtain peak parameters, Raman mode frequencies, and peak widths [full width at half maximum (FWHM)] from these spectra.

\section{Results}

\subsection{P-V Equation of State and Raman Spectroscopy}

The unit-cell parameters and volumes of topaz at various pressures up to $13.4 \mathrm{GPa}$ are shown in Table 1. Moreover, the $V / V_{0}$ as a function of pressure are plotted in Figure 2. With the increasing pressure, no abrupt change in the unit-cell volumes were observed in Figure 2, indicating that there is no phase transition within this pressure range.

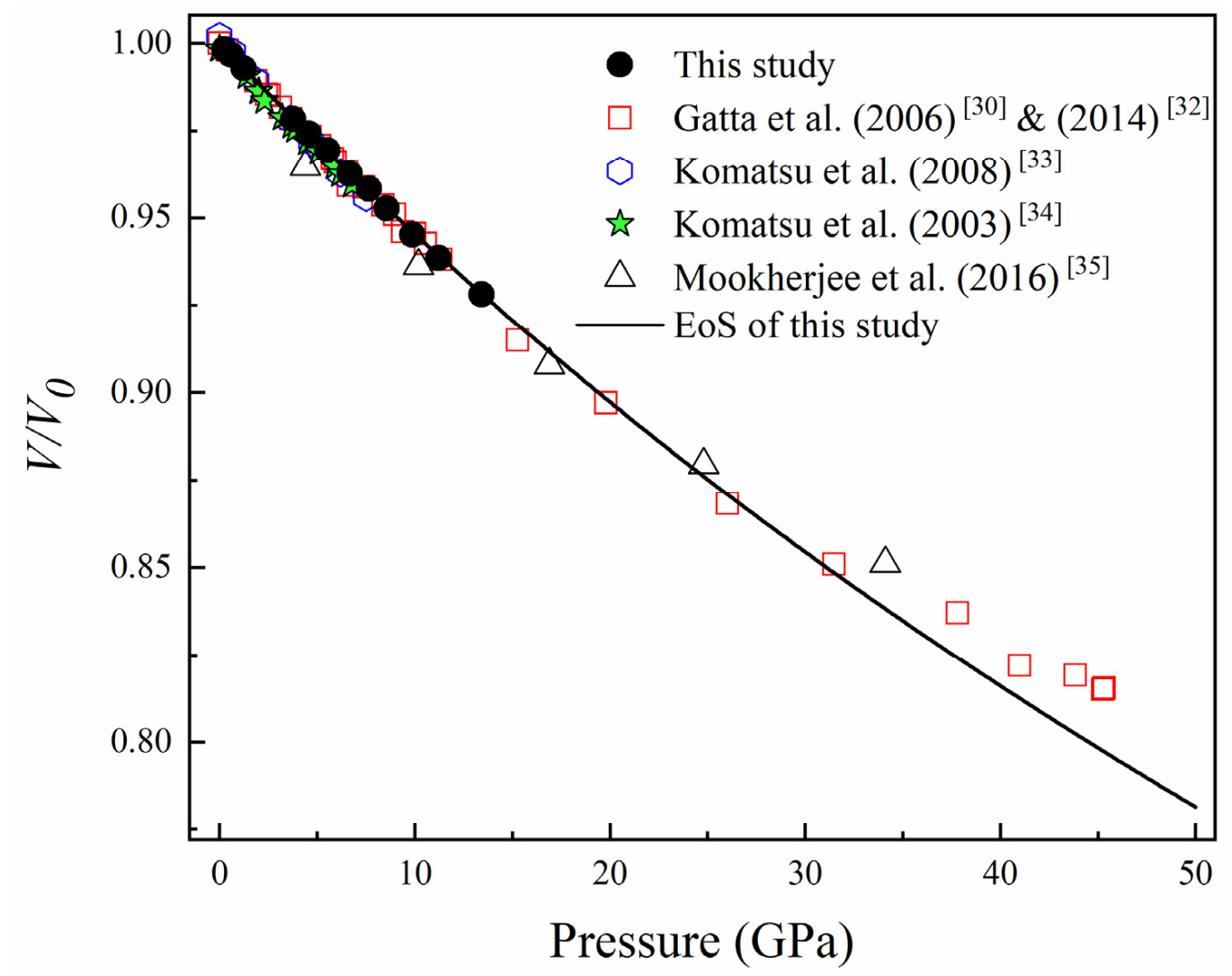

Figure 2. The $V / V_{0}$ changed with the pressure, the black solid points represent the data points measured in this experiment, and the black lines were obtained by BM3 EoS-fitting. The red hollow square represents the data points of Gatta et al. (2006) [30] \& (2014) [32], the blue hollow hexagon represents the data points of Komatsu et al. (2008) [33], the green solid pentacle represents the data points of Komatsu et al. (2003) [34], and the black hollow triangle represents the data points of Mookherjee et al. (2016) [35]. 
The $P-V$ data (Table 1) were fitted using the third-order Birch-Murnaghan EoS as follows:

$$
P=(3 / 2) K_{0}\left[\left(V_{0} / V\right)^{7 / 3}-\left(V_{0} / V\right)^{5 / 3}\right] \times\left[1+(3 / 4)\left(K_{0}^{\prime}-4\right)\left[\left(V_{0} / V\right)^{2 / 3}-1\right]\right]
$$

where $V_{0}, K_{0}$, and $K_{0}^{\prime}$ are the zero-pressure volume, isothermal bulk modulus, and its pressure derivative, respectively. Analyses of Equation (1) by the EoSFit 7c program (7.5, University of Padova, Veneto, Italy) [51] with all parameters free, obtained the following results: $V_{0}=343.86$ (9) $\AA^{3}$, $K_{0}=172(3) \mathrm{GPa}$, and $K_{0}^{\prime}=1.3(4)$. When $K_{0}^{\prime}$ fixed at 4 , the fitting results yielded $V_{0}=344.2(2) \AA^{3}$ and $K_{0}=155$ (2) GPa. The relationship between the Eulerian definition of finite strain $f_{E}\left(f_{E}=\left[\left(V_{0} / V\right)^{2 / 3}-1\right] / 2\right)$ and "normalized stress" $F_{E}\left(F_{E}=P / 3 f_{E}\left(1+2 f_{E}\right)^{5 / 2}\right)$ is shown in Figure 3 [52]. The weighted linear fit of the data points yielded the intercept value of $F_{E}(0)=172(2) \mathrm{GPa}$, which is consistent with the isothermal bulk modulus obtained by the third-order Birch-Murnaghan EoS $\left(K_{0}=172\right.$ (3) GPa). Moreover, the relationship between $F_{E}$ and $f_{E}$ has a negative slope, indicating that $K^{\prime}{ }_{0}$ is less than 4 . This is consistent with $K_{0}^{\prime}=1.3$ (4) obtained from the third-order Birch-Murnaghan EoS [52]. Therefore, the third-order Birch-Murnaghan EoS is a good description of the $P-V$ data in this study.

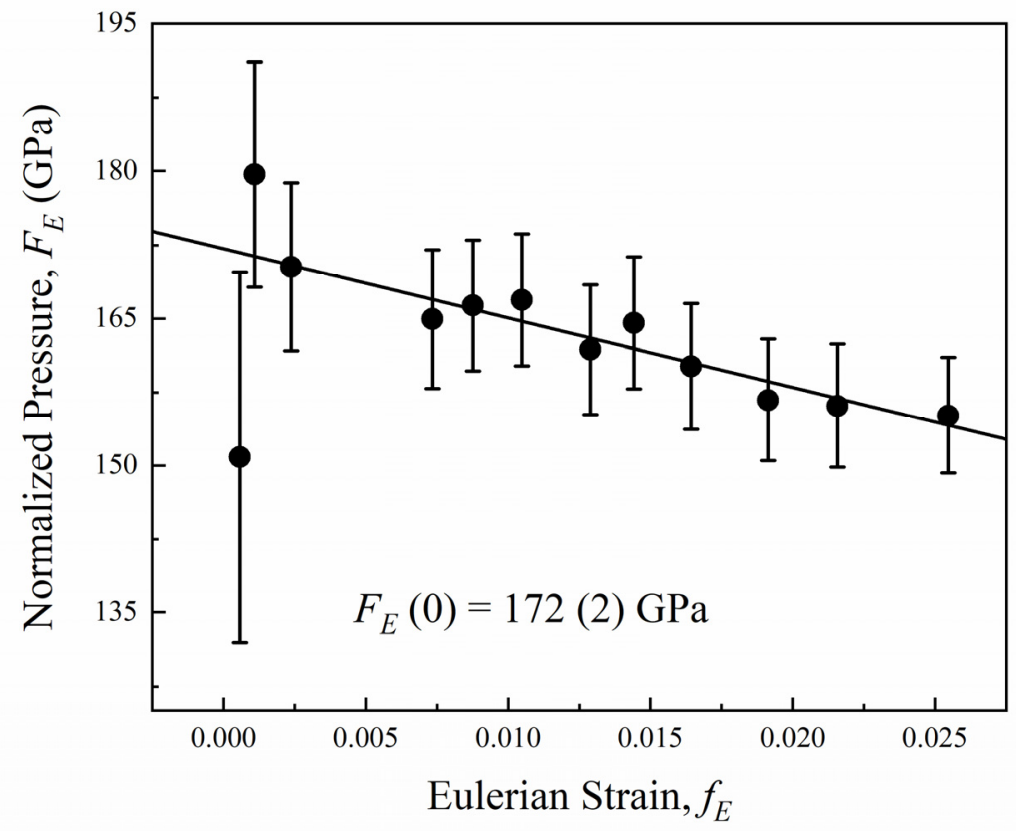

Figure 3. Volume Eulerian strain-normalized pressure $\left(F_{E}-f_{E}\right)$ plot. The solid line is the linear fit of the data.

High-pressure Raman spectra of topaz were also collected up to $24.4 \mathrm{GPa}$. Typical Raman spectra at selected pressures are shown in Figure 4. No evidence for a phase transition of topaz was observed up to $24.4 \mathrm{GPa}$. With the pressure increasing, ten Raman peaks of topaz gradually shifted to high frequencies in the range of $200-1200 \mathrm{~cm}^{-1}$. It is worth noting that two peaks at about $924.6 \mathrm{~cm}^{-1}$ overlapped at $0.2 \mathrm{GPa}$ and separated at $10.8 \mathrm{GPa}$ and higher pressures.

According to the results of previous studies, these ten kinds of vibration peaks can be assigned to six vibration modes $[53,54]$. Among the ten vibration modes, six vibration modes are symmetric Si-O ring deformations $\left(v_{1}\right)$. The other four vibration modes are vibrational modes of $\left[\mathrm{SiO}_{4}\right]$ tetrahedrons $\left(v_{2}\right)$, stretching modes of Al-F $\left(v_{3}\right)$, stretching modes of $\left[\mathrm{AlO}_{6}\right]$ octahedrons $\left(v_{4}\right)$, stretching and bending modes of $\left[\mathrm{AlO}_{6}\right]$ octahedrons, and bending modes of $\left[\mathrm{SiO}_{4}\right]$ tetrahedrons $\left(v_{5}\right)$, and in-plane bending OH-groups $\left(v_{6}\right)[53,54]$. Figure 5 shows several vibration mode frequencies as a function of pressure. Except for the $v_{6}$ vibration mode, other vibration modes are linear. With the increase in pressure, all bands move to high frequencies. Table 2 summarizes the Raman spectra results of topaz under high pressures in this study, which shows that the pressure derivatives of Raman shift $(\mathrm{d} v / \mathrm{d} P)$ are 
in the range of $0.93-5.12 \mathrm{~cm}^{-1} / \mathrm{GPa}$. At last, the results of our high-pressure single-crystal XRD and Raman spectroscopy experiments clearly indicate that topaz can be metastable up to $24.4 \mathrm{GPa}$ at room temperature.

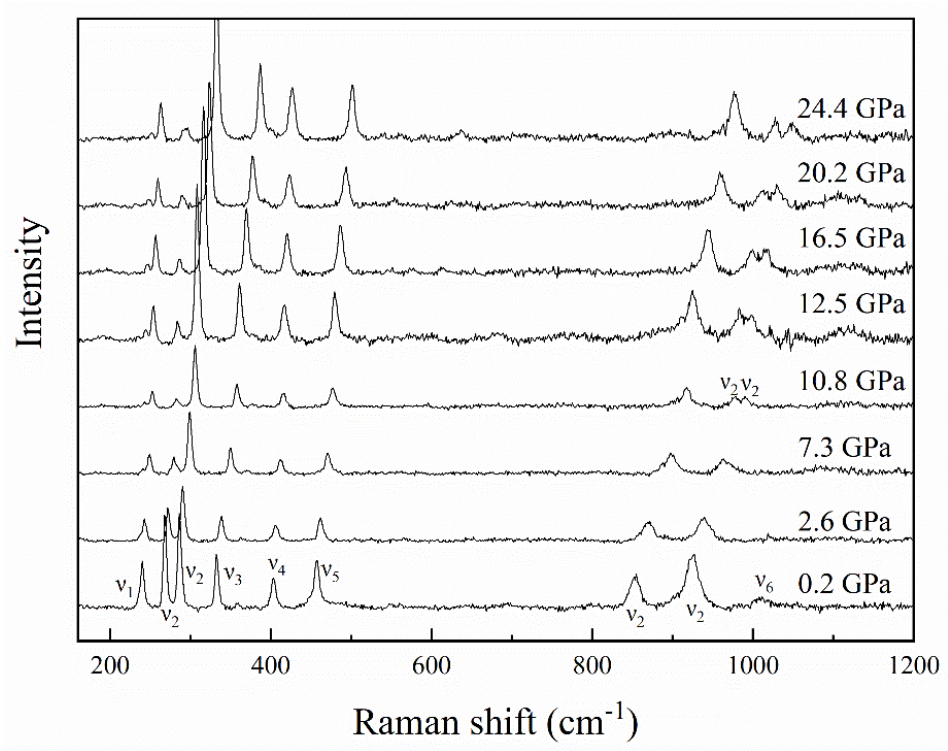

Figure 4. Representative Raman spectra of topaz up to $24.4 \mathrm{GPa} . v_{1}$, Symmetric Si-O ring deformation, $v_{2}$, Vibrational modes of $\left[\mathrm{SiO}_{4}\right]$ tetrahedra, $v_{3}$, Stretching modes of Al-F, $v_{4}$, Stretching modes of $\left[\mathrm{AlO}_{6}\right]$ octahedra, $v_{5}$, Stretching and bending modes of $\left[\mathrm{AlO}_{6}\right]$ octahedra and bending modes of $\left[\mathrm{SiO}_{4}\right]$ tetrahedra, $v_{6}$, In-plane bending $\mathrm{OH}$-groups.

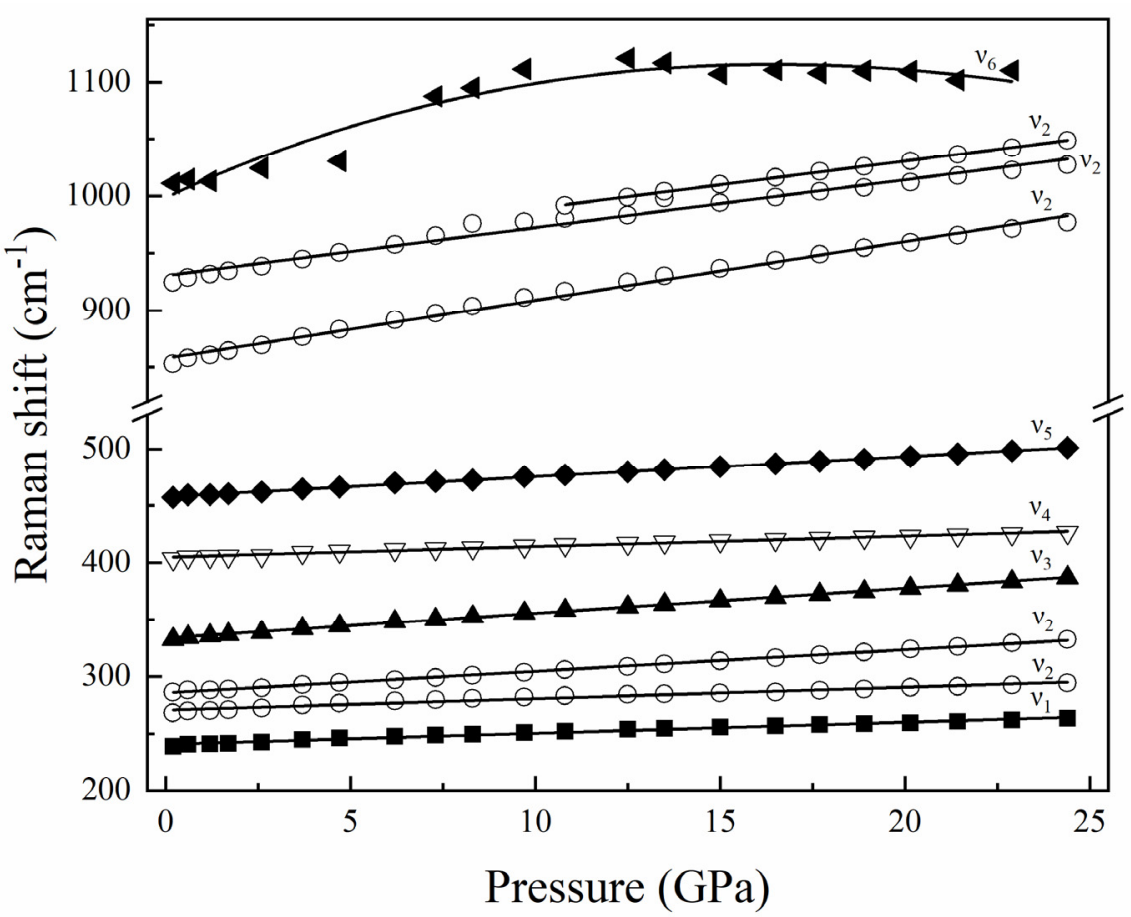

Figure 5. Pressure dependences of the observed Raman modes for topaz up to $24.4 \mathrm{GPa} . v_{1}$, Symmetric Si-O ring deformation, $v_{2}$, Vibrational modes of $\left[\mathrm{SiO}_{4}\right]$ tetrahedra, $v_{3}$, Stretching modes of Al-F, $v_{4}$, Stretching modes of $\left[\mathrm{AlO}_{6}\right]$ octahedra, $v_{5}$, Stretching and bending modes of $\left[\mathrm{AlO}_{6}\right]$ octahedra and bending modes of $\left[\mathrm{SiO}_{4}\right]$ tetrahedra, $v_{6}$, In-plane bending $\mathrm{OH}$-groups. 
Table 2. Mode shifts, derivative of Raman shift to pressure, and mode Grüneisen parameter of topaz.

\begin{tabular}{cccc}
\hline $\boldsymbol{\omega}_{\mathbf{0}}\left(\mathbf{c m}^{-\mathbf{1}}\right)$ & $\mathbf{d} \boldsymbol{\omega} / \mathbf{d P}\left(\mathbf{c m}^{-\mathbf{1}} / \mathbf{G P a}\right)$ & Grüneisen Parameters & Assignment \\
\hline $991.7(6)$ & $4.16(3)$ & $0.721(6)$ & $v_{2}$ \\
$924.6(2)$ & $4.2(1)$ & $0.78(3)$ & $v_{2}$ \\
$852.9(1)$ & $5.12(9)$ & $1.03(2)$ & $v_{2}$ \\
$457.2(1)$ & $1.77(1)$ & $0.667(6)$ & $v_{5}$ \\
$403.5(1)$ & $0.93(2)$ & $0.395(9)$ & $v_{4}$ \\
$332.52(7)$ & $2.20(2)$ & $1.14(1)$ & $v_{3}$ \\
$286.38(6)$ & $1.88(1)$ & $1.13(1)$ & $v_{2}$ \\
$268.14(5)$ & $1.00(4)$ & $0.64(3)$ & $v_{2}$ \\
$239.8(1)$ & $0.96(3)$ & $0.69(2)$ & $v_{1}$ \\
\hline
\end{tabular}

$v_{1}$ : Symmetric Si-O ring deformation; $v_{2}$ : Vibrational modes of $\left[\mathrm{SiO}_{4}\right]$ tetrahedral; $v_{3}$ : Stretching modes of Al-F; $v_{4}$ : Stretching modes of $\left[\mathrm{AlO}_{6}\right]$ octahedral; $v_{5}$ : Stretching and bending modes of $\left[\mathrm{AlO}_{6}\right]$ octahedra and bending modes of $\left[\mathrm{SiO}_{4}\right]$ tetrahedra.

\subsection{Thermal Expansion of Topaz}

The high-temperature $X R D$ data were collected to $713 \mathrm{~K}$ at ambient pressure. All of the XRD patterns at each temperature of topaz are similar up to $713 \mathrm{~K}$, with Bragg peaks shifted to lower $2 \theta$, indicating that topaz did not undergo any phase transition up to the experimental maximum temperature $(713 \mathrm{~K})$ (Figure 6). Figure $7 \mathrm{a}-\mathrm{d}$ shows the typical Le Bail profile fitting results of the XRD profiles at $298 \mathrm{~K}, 413 \mathrm{~K}, 533 \mathrm{~K}$, and $713 \mathrm{~K}$, respectively. Unit-cell parameters and volumes $(a, b, c$, and $V$ ) at all temperature points from $298 \mathrm{~K}$ to $713 \mathrm{~K}$ with an interval of $30 \mathrm{~K}$ are given in Table 3.

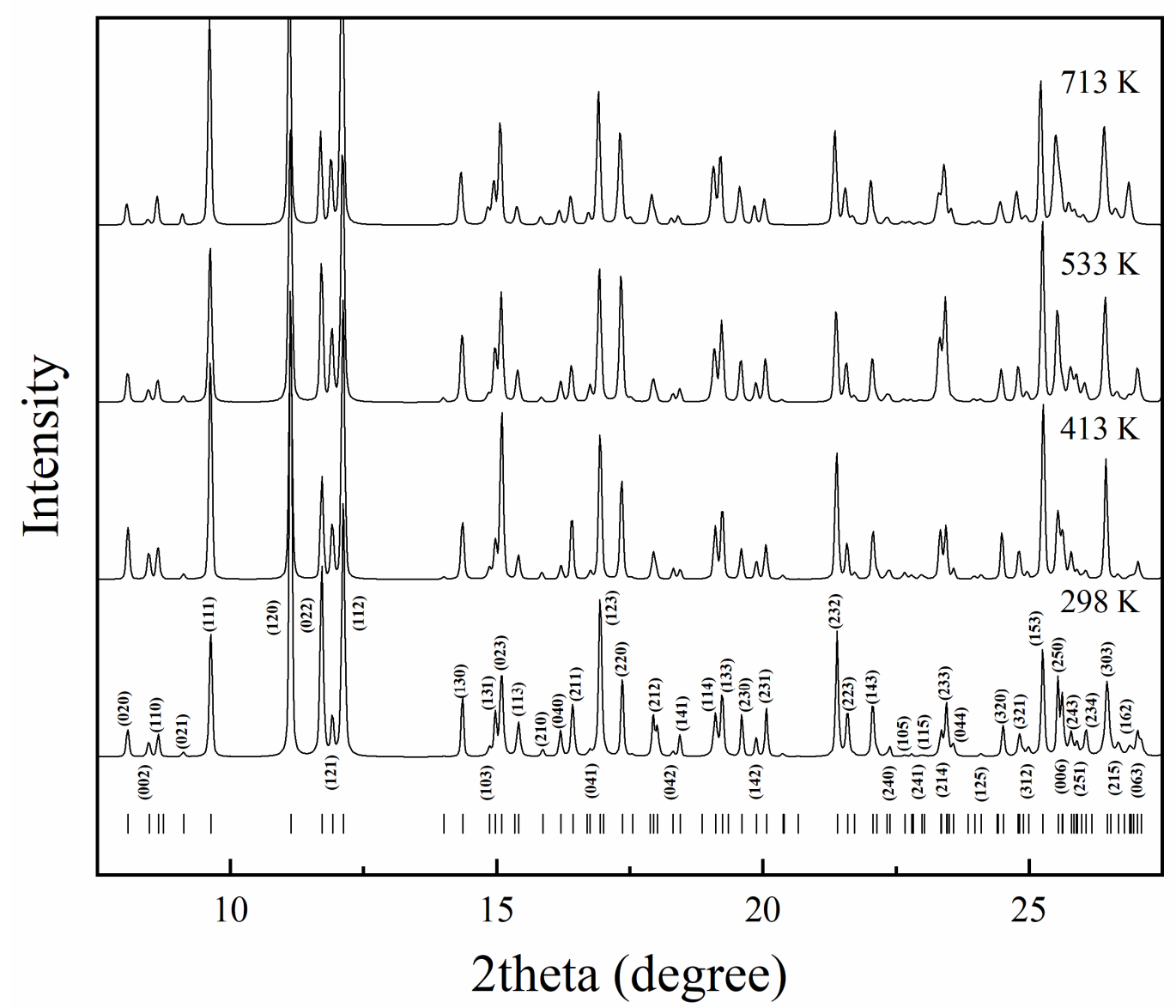

Figure 6. Typical X-ray diffraction patterns of topaz from powder $\mathrm{X}$-ray diffraction experiments at ambient pressure and high temperature. 

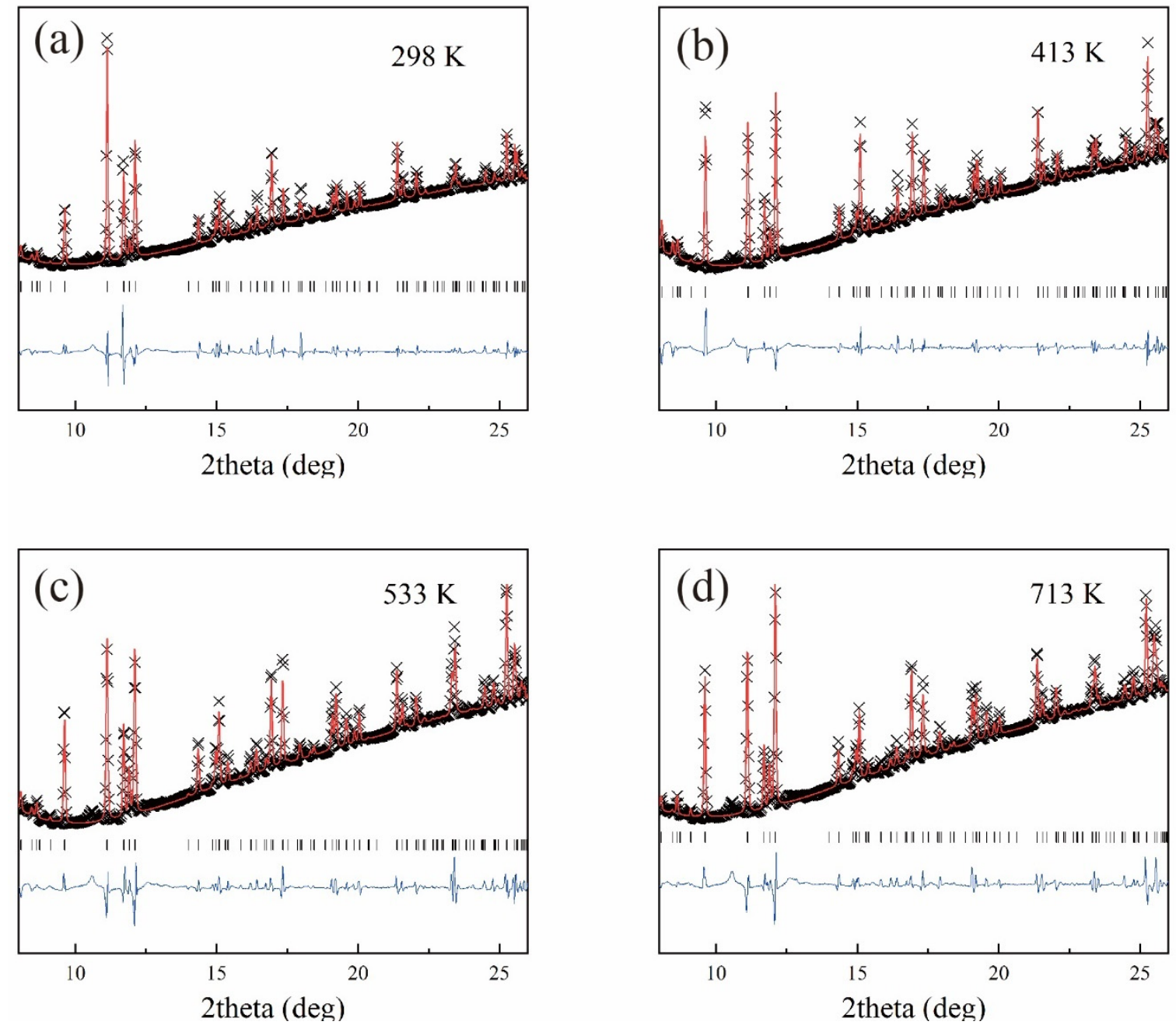

Figure 7. The representative Le Bail profile fitting pattern of topaz at $298 \mathrm{~K}$ (a), $413 \mathrm{~K}$ (b), $533 \mathrm{~K}$ (c), and $713 \mathrm{~K}(\mathbf{d})$. Observed spectra (black line), fitted spectra (red solid line), difference plot (blue solid line), and Bragg peak positions (tick marks) are shown.

Table 3. The unit-cell parameters of topaz at high temperature and ambient pressure.

\begin{tabular}{ccccc}
\hline Temperature (K) & $\boldsymbol{a}(\mathbf{\AA})$ & $\boldsymbol{b}(\mathbf{A})$ & $\boldsymbol{c}(\mathbf{\AA})$ & $\boldsymbol{V}\left(\mathbf{\AA}^{\mathbf{3}}\right)$ \\
\hline 298 & $4.6411(3)$ & $8.7912(6)$ & $8.3804(6)$ & $341.92(4)$ \\
323 & $4.6440(2)$ & $8.7873(4)$ & $8.3799(4)$ & $341.96(3)$ \\
353 & $4.6440(2)$ & $8.7894(4)$ & $8.3787(4)$ & $342.00(3)$ \\
383 & $4.6453(2)$ & $8.7884(5)$ & $8.3782(4)$ & $342.04(3)$ \\
413 & $4.6462(2)$ & $8.7860(5)$ & $8.3794(5)$ & $342.06(3)$ \\
443 & $4.6461(2)$ & $8.7861(4)$ & $8.3822(5)$ & $342.17(3)$ \\
473 & $4.6448(3)$ & $8.7869(4)$ & $8.3892(5)$ & $342.39(3)$ \\
503 & $4.6453(2)$ & $8.7889(4)$ & $8.3888(5)$ & $342.49(3)$ \\
533 & $4.6480(3)$ & $8.7883(5)$ & $8.3863(6)$ & $342.56(4)$ \\
563 & $4.6488(3)$ & $8.7936(4)$ & $8.3825(5)$ & $342.67(3)$ \\
593 & $4.6488(3)$ & $8.7942(6)$ & $8.3868(6)$ & $342.87(4)$ \\
623 & $4.6476(3)$ & $8.7984(6)$ & $8.3893(5)$ & $343.05(4)$ \\
653 & $4.6487(3)$ & $8.7991(5)$ & $8.3896(6)$ & $343.17(4)$ \\
683 & $4.6506(3)$ & $8.8000(7)$ & $8.3891(7)$ & $343.33(5)$ \\
713 & $4.6506(3)$ & $8.8017(6)$ & $8.3921(6)$ & $343.51(4)$ \\
\hline
\end{tabular}


Figure 8 shows the variations of the unit-cell volumes with temperature. When the temperature increased from $300 \mathrm{~K}$ to $713 \mathrm{~K}$, the unit-cell volume increased by $0.5 \%$. We used Fei's thermal expansion equation to fit our high-temperature $X R D$ data:

$$
V_{\mathrm{T}}=V_{0} \exp \left(\alpha_{0}\left(T-T_{\text {ref }}\right)+(1 / 2) \alpha_{1}\left(T^{2}-\mathrm{T}_{\text {ref }}^{2}\right)-\alpha_{2}\left((1 / T)-\left(1 / T_{\text {ref }}\right)\right)\right)
$$

where $V_{\mathrm{T}}$ represents the unit-cell volume at high temperature and ambient pressure, $V_{0}$ represents the unit-cell volume at ambient conditions, and $T_{\text {ref }}$ is the reference temperature. $\alpha_{0}, \alpha_{1}$, and $\alpha_{2}$ are the three parameters to describe the relationship between the thermal expansion coefficient and the temperature with the form of $\alpha_{\mathrm{T}}=\alpha_{0}+\alpha_{1} T+\alpha_{2} T^{-2}$. Since our experimental temperature range was limited, $\alpha_{1}=\alpha_{2}=0$ was set in the fitting process and the $\alpha_{T}$ equal to $\alpha_{0}$. It can be seen from Figure 8 that most of the high-temperature $X R D$ data points fall on the fitting line, which indicates that Fei's equation was suitable for fitting the high-temperature XRD data in this study. By fitting our high-temperature XRD data using Equation (2), we obtained the thermal expansion coefficient $\alpha_{300}=1.9(1) \times 10^{-5} \mathrm{~K}^{-1}$, as shown in Table 4 . The thermal expansion coefficient obtained in this study is consistent with Komatsu's [34] results $\left(\alpha_{300}=2.0(1) \times 10^{-5} \mathrm{~K}^{-1}\right)$.

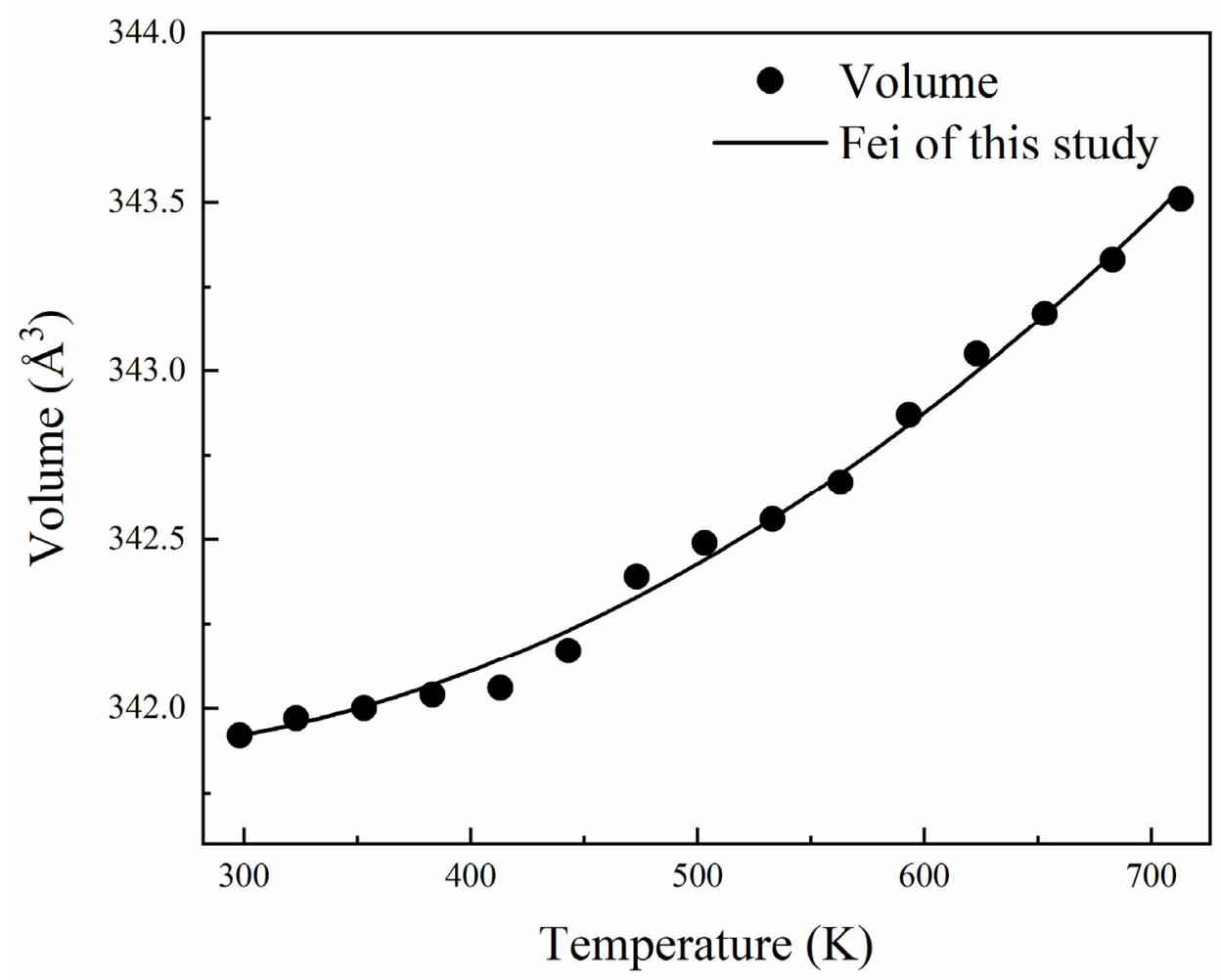

Figure 8. Temperature-Volume $(T-V)$ data of topaz at ambient pressure and high temperature. 
Table 4. Comparison of thermoelasticity of Topaz.

\begin{tabular}{|c|c|c|c|c|c|c|c|c|}
\hline Samples & $\begin{array}{c}P \\
(\mathrm{GPa})\end{array}$ & $\begin{array}{c}T \\
(\mathrm{~K})\end{array}$ & $\begin{array}{c}\mathrm{K}_{0} \\
(\mathrm{GPa})\end{array}$ & $K_{0}^{\prime}$ & $\begin{array}{c}\alpha\left(10^{-5} / \mathrm{K}\right) \\
\text { at } 300 \mathrm{~K}\end{array}$ & Methods & Pressure Medium & References \\
\hline $\mathrm{Al}_{2.00} \mathrm{Si}_{1.05} \mathrm{O}_{4.00}\left(\mathrm{OH}_{0.26} \mathrm{~F}_{1.75}\right)$ & 10.55 & 300 & $164(2)$ & $2.9(4)$ & - & $\mathrm{SC}-X R D^{\mathrm{a}}$ & methanol: ethanol: water (16:3:1) & Gatta et al. (2006) [30] \\
\hline $\mathrm{Al}_{2.00} \mathrm{Si}_{1.05} \mathrm{O}_{4.00}\left(\mathrm{OH}_{0.26} \mathrm{~F}_{1.75}\right)$ & 45 & 300 & $158(4)$ & $3.3(3)$ & - & SC-XRD & Neon & Gatta et al. (2014) [32] \\
\hline $\mathrm{Al}_{2} \mathrm{SiO}_{4}\left(\mathrm{OD}_{1.45}, \mathrm{OH}_{0.55}\right)_{\Sigma 2.0}$ & 7.5 & 300 & $145(4)$ & 4 (fixed) & - & $\mathrm{NPD}^{\mathrm{c}}$ & methanol: ethanol (4:1) & Komatsu et al. (2008) [33] \\
\hline $\mathrm{Al}_{2.01} \mathrm{SiO}_{4} \mathrm{~F}_{1.57}(\mathrm{OH})_{0.43}$ & 6.2 & 300 & $154(2)$ & 4 (fixed) & - & $S C-X R D$ & methanol: ethanol: water $(16: 3: 1)$ & Komatsu et al. (2003) [34] \\
\hline $\mathrm{Al}_{2.01} \mathrm{SiO}_{4} \mathrm{~F}_{1.57}(\mathrm{OH})_{0.43}$ & 0.0001 & 1173 & - & - & $2.0(1)$ & $P C-X R D^{b}$ & - & Komatsu et al. (2003) [34] \\
\hline $\mathrm{Al}_{2} \mathrm{SiO}_{4}(\mathrm{OH})_{2}$ & 38.6 & 300 & $166.4(6)$ & $4.03(4)$ & - & FPS $^{\mathrm{d}}$ & - & Mookherjee et al. (2016) [35] \\
\hline $\mathrm{Al}_{2} \mathrm{SiO}_{4} \mathrm{~F}(\mathrm{OH})$ & 50 & 300 & $165(3)$ & $3.4(4)$ & - & FPS\&QMA ${ }^{\mathrm{e}}$ & - & Ulian et al. (2017) [36] \\
\hline $\mathrm{Al}_{1.935}\left[\left(\mathrm{Si}_{0.935} \mathrm{Al}_{0.065}\right) \mathrm{O}_{4.000}\right]\left(\mathrm{OH}_{0.408} \mathrm{~F}_{1.592}\right)$ & 13.4 & 300 & $172(3)$ & $1.3(4)$ & - & $\mathrm{SC}-\mathrm{X} R D$ & Neon & This study \\
\hline $\mathrm{Al}_{1.935}\left[\left(\mathrm{Si}_{0.935} \mathrm{Al}_{0.065}\right) \mathrm{O}_{4.000}\right]\left(\mathrm{OH}_{0.408} \mathrm{~F}_{1.592}\right)$ & 13.4 & 300 & $155(2)$ & 4 (fixed) & - & $\mathrm{SC}-\mathrm{XRD}$ & Neon & This study \\
\hline $\mathrm{Al}_{1.935}\left[\left(\mathrm{Si}_{0.935} \mathrm{Al}_{0.065}\right) \mathrm{O}_{4.000}\right]\left(\mathrm{OH}_{0.408} \mathrm{~F}_{1.592}\right)$ & 0.0001 & 713 & - & - & $1.9(1)$ & PC-XRD & - & This study \\
\hline
\end{tabular}




\section{Discussion}

\subsection{P-V Equation of State}

Figure 2 shows the volume compression $\left(V / V_{0}\right)$ of topaz as a function of pressure in this study and a comparison with the results from previous studies. The solid curves in Figure 2 are the calculated compression curve with $K_{0}=172$ (3) GPa and $K_{0}^{\prime}=1.3$ (4) for the topaz in this study. From Figure 2, we can find that our data are consistent with most the previous experimental data within 13.4 GPa [30,32-34], but are a little different from the theoretical data of Mookherjee et al. (2016) [35].

The comparison of $K_{0}$ and $K_{0}^{\prime}$ in this study and previous studies for topaz is summarized in Table 4. The EoS of topaz has been extensively studied by experiments and theoretical calculation, but there is a large difference among the $K_{0}$ of previous studies (Table 4). Detailed analysis results of previous studies show that different sample compositions and experimental methods may have an important influence on the EoS parameters $\left(K_{0}\right.$ and $\left.K_{0}^{\prime}\right)$ of topaz. Furthermore, compared with previous results (Table 4), the obtained $K_{0}=172$ (3) GPa and $K_{0}^{\prime}=1.3(4)$ in this study were 3.3-8.1\% larger and 55.2-67.7\% smaller than those obtained in previous studies within their uncertainties, respectively.

We infer that there are three possible reasons for the difference in $K_{0}$ of topaz. Initially, the compositional differences among different studies of topaz are some of the most important factors. For example, the compositions among this study, Gatta et al. (2006) [30], and Komatsu et al. (2003) [34] are different (Table 4), which may cause the difference among the obtained $K_{0}$ (Figure 9). In addition, in static compression studies, there is a trade-off between the fitted $K_{0}$ and $K_{0}^{\prime}$, which have a negative correlation [55]. Our result of $K_{0}^{\prime}=1.3$ (4) was less than those reported by previous studies (2.9-4.03), and accordingly, $K_{0}$ was larger. Therefore, the difference in $K_{0}^{\prime}$ may be another cause of the different $K_{0}$ of topaz (Figure 10). Moreover, the pressure medium is also a factor that affects the result of $K_{0}$ value. The hydrostatic limit of 4:1 methanol-ethanol and 16:3:1 methanol-ethanol-water mixtures is about 9.8-10.5 GPa, while that of the neon can reach $15 \mathrm{GPa}[56,57]$. Gatta et al. $(2006,2014)[30,32]$ used neon and 16:3:1 methanol-ethanol-water mixtures as the pressure medium, and found the difference between the obtained $K_{0}$ was 3.7\%. Furthermore, Komatsu et al. $(2003,2008)[33,34]$ used 4:1 methanol-ethanol mixtures and 16:3:1 methanol-ethanol-water mixtures as the pressure medium, respectively, and indicated that the difference of $K_{0}$ between them and Gatta et al. $(2006,2014)$ was 2.5-8.2\% [32-34]. Considering the above three factors, we further compared the fitted $K_{0}$ of this study with Komatsu et al. (2003) [34] at fixed $K_{0}^{\prime}=4$, which had a similar sample composition and the hydrostatic environment with this study, and found that the obtained $K_{0}=155$ (2) GPa of this study is consistent with the result of Komatsu et al. (2003) [34].

\subsection{P-T Phase Diagram and Stability of Topaz under High P-T Conditions}

A hydrous mineral is one of the important constituent minerals of the subducted plate [2]. The P-T stability and dehydration of hydrous minerals have a profound effect on understanding the dynamic process of plate subduction [5]. Under the $P$-T conditions of cold subduction, especially ultra-cold subduction, the dehydration of hydrous minerals is likely to be restrained by the low-temperature condition, which may push them into the deep mantle along with the subducted plates and transport a large amount of water into the middle and lower part of the upper mantle, thus exerting a profound influence on the geological process of deep Earth [17,18,23,58].

Topaz, as an important aluminosilicate mineral that occurs in the shallow crust, is an important carrier of $\mathrm{F}$ and $\mathrm{H}_{2} \mathrm{O}$. Moreover, as mentioned in the introduction part, topaz in granitoid might reach depths of 200-300 km with continent crust subduction [17,19,22,23]. Figure 11 shows the P-T stability area and metastable area of topaz. The stability area was obtained from Wunder et al. and Ono et al. experimental data $[18,23]$, and the metastable area was obtained from this study and other previous studies [30,32-35]. 


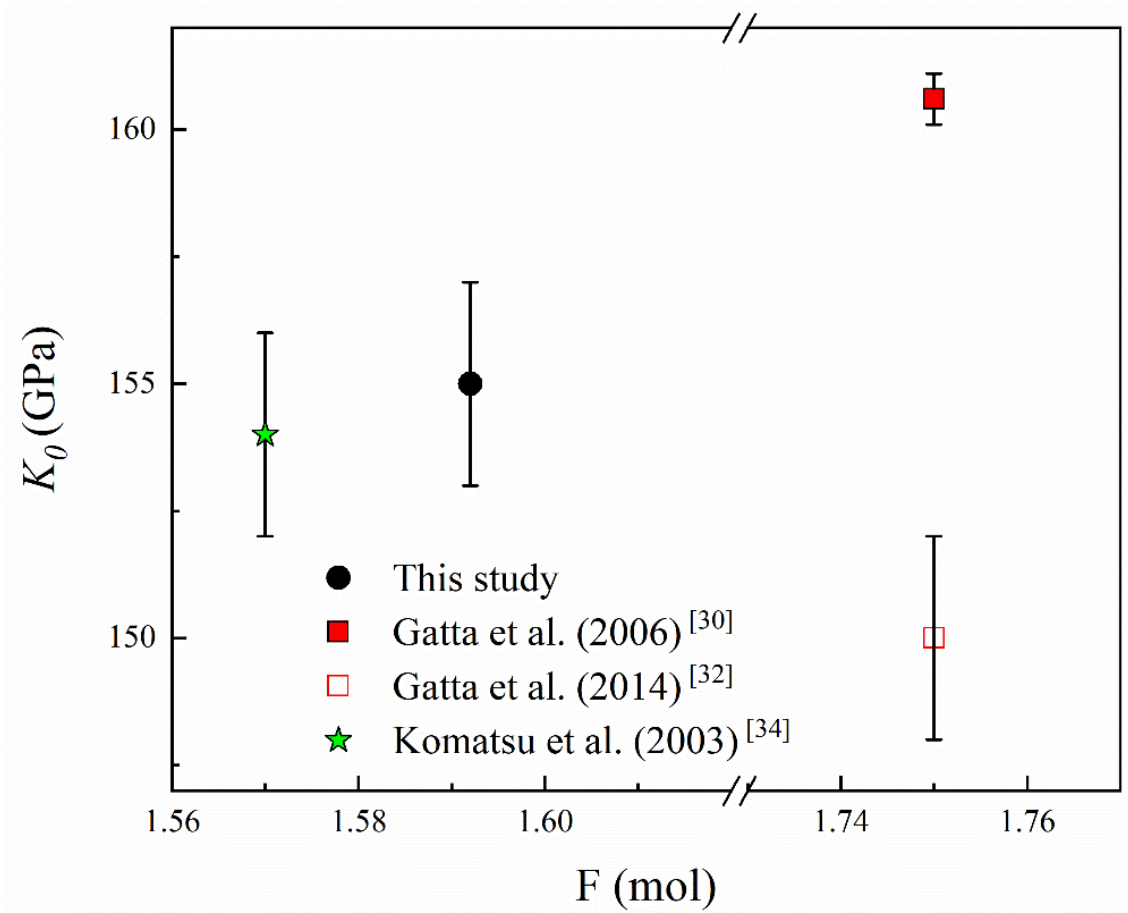

Figure 9. The relationship between $K_{0}$ and $\mathrm{F}$ content. The red solid square represents the data points of Gatta et al. (2006) [30], the red hollow square represents the data points of Gatta et al. (2014) [32], and the green solid pentacle represents the data points of Komatsu et al. (2003) [34].

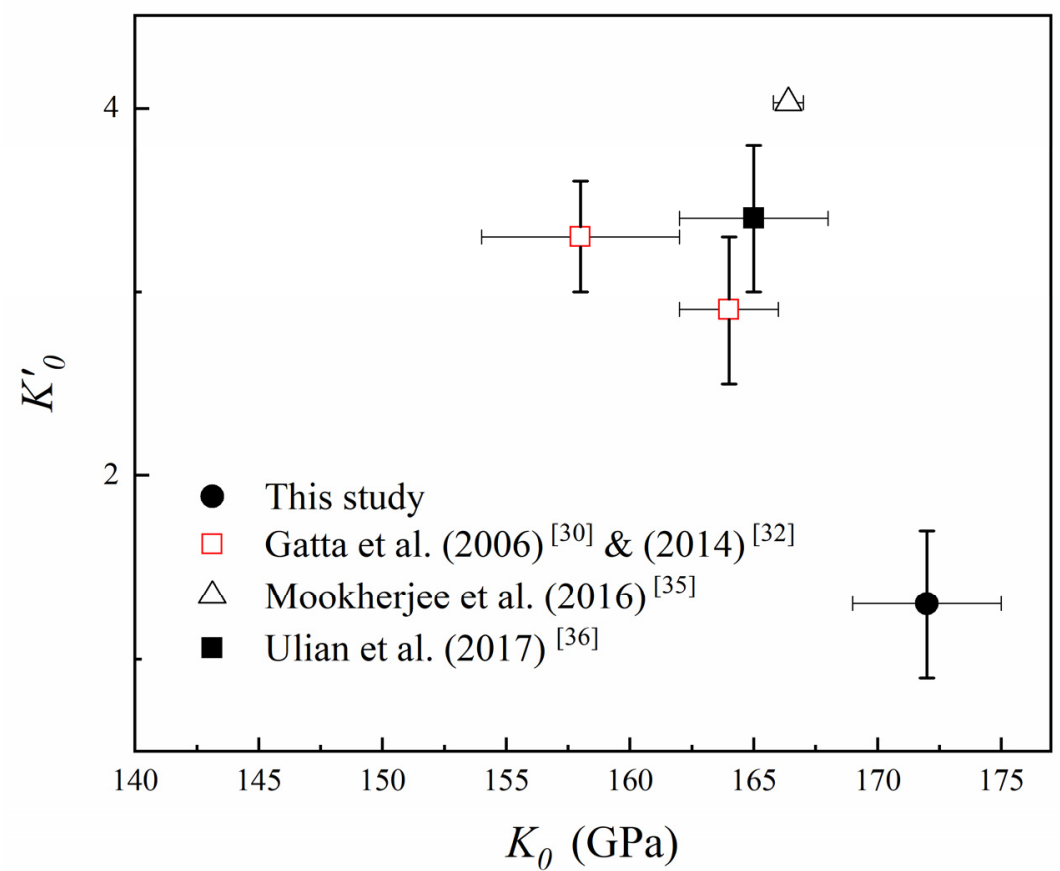

Figure 10. The relationship between $K_{0}$ and $K_{0}^{\prime}$ value. The red hollow square represents the data points of Gatta et al. (2006) [30] \& (2014) [32], the black hollow triangle represents the data points of Mookherjee et al. (2016) [35], and the black solid square represents the data points of Ulian et al. (2017) [36].

Under the normal geothermal gradient conditions (1.3-12.7 GPa, 740-1700 K) [59-61], the stability depth of topaz is in the range of about $248 \mathrm{~km}$ to $413 \mathrm{~km}$ (7.5 to $12.5 \mathrm{GPa}, 1244-1700 \mathrm{~K})$. However, the stability depth of topaz is quite different in subduction zones. As shown in Figure 11, although 
in the case of hot subduction zones, such as Aleutian (2.2-13.7 GPa, 740-1260 K), the stability depth of topaz is in the range of about $120 \mathrm{~km}$ to $396 \mathrm{~km}$ (5-12 GPa, 970-1200 K), topaz may be completely devolatilized at depths above $100 \mathrm{~km}$ and cannot carry $\mathrm{F}$ and $\mathrm{H}_{2} \mathrm{O}$ into the deep upper mantle [62,63]. Contrarily, in the case of cold subduction zones, such as Tonga (2.1-15.7 GPa, 425-708 K), topaz may be metastable at depths above $350 \mathrm{~km}(2.1-10.5 \mathrm{GPa}, 425-613 \mathrm{~K})$ [62]. It is consistent with the results of this experiment that topaz is stable under $700 \mathrm{~K}$ and $10.9 \mathrm{GPa}$. Furthermore, as mentioned above, the maximum $\mathrm{OH}$ content of topaz is about $10 \mathrm{wt} . \%$. However, the water content of olivine is in the range of $49 \mathrm{ppm}$ to $392 \mathrm{ppm}$ [64], the water content of ortho- and clinopyroxenes is in the range of $215 \mathrm{ppm}$ to $263 \mathrm{ppm}$ and $195 \mathrm{ppm}$ to $620 \mathrm{ppm}$, respectively [65], and the water content of garnet is in the range of $50 \mathrm{ppm}$ to $150 \mathrm{ppm}$ [66]. Therefore, topaz contains much more water than nominally anhydrous minerals, even though its content is much less in the slab than that of nominally anhydrous minerals. According to the present study, topaz can carry plenty of $\mathrm{H}_{2} \mathrm{O}$ and $\mathrm{F}$ to the deepest depth of $370 \mathrm{~km}$ in the coldest subduction zones (Figure 11). Due to the temperature of the surrounding mantle being much higher than that of the subduction slab, the temperature of the subduction slab will rise with time. Consequently, topaz will devolatilize. Hence, the released $\mathrm{F}$ and $\mathrm{H}_{2} \mathrm{O}$ from topaz may potentially affect the geochemical behavior of the upper mantle [67].

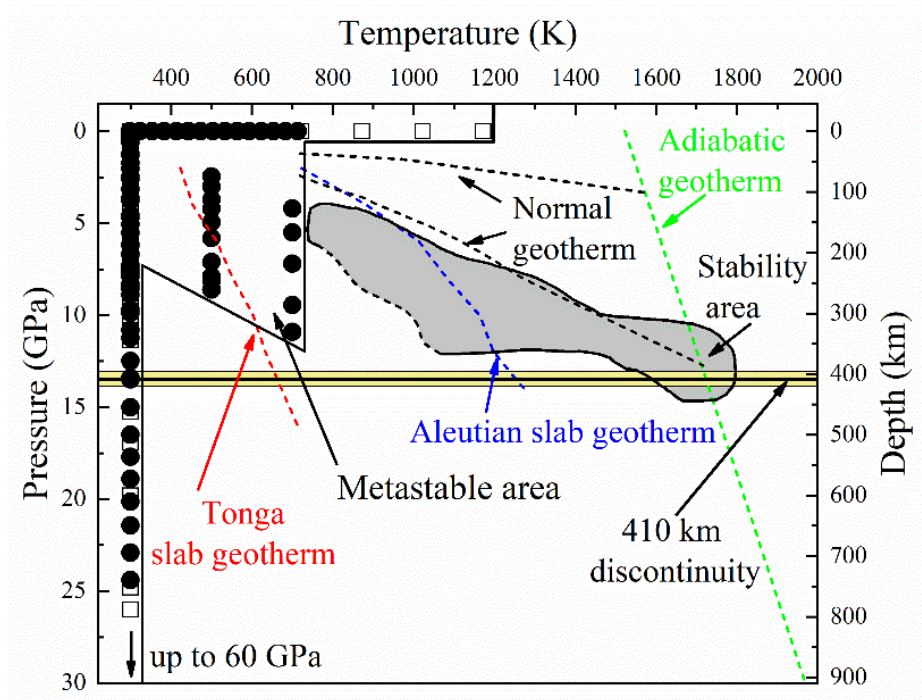

Figure 11. The $P-T$ stability of topaz. Data of $P-T$ stable area were obtained from Wunder et al. (1993) [18,22] and Ono et al. (1999) [23]. In the metastable area, black solid points are the data points of this experiment, and other data were obtained from Komatsu et al. (2003) [34], Gatta et al. (2006) [30], Komatsu et al. (2008) [33], Gatta et al. (2014) [32], Mookherjee et al. (2016) [35]. The dotted lines represent the Tonga slab geotherm (red), Aleutian slab geotherm (blue) (Bina and Navrotsky (2000) [62]), Normal geotherm (black) (Pollack and Chapman (1977) [59]), and adiabatic geotherm (green) (Artemieva et al. (2001) [61] and Zang et al. (2002) [60]).

\section{Conclusions}

The $P-V$ and $T-V$ relationship, and the $P-T$ stability of topaz were carried out using the synchrotron-based single-crystal XRD and Raman spectroscopy methods up to $713 \mathrm{~K}$ and $24.4 \mathrm{GPa}$ in this study. There was no phase transition in the maximum $P-T$ conditions in this study. $P-V$ data fitted by third-order Birch-Murnaghan EoS, obtained $V_{0}=343.86$ (9) $\AA^{3}, K_{0}=172$ (3) GPa, and $K_{0}^{\prime}=1.3$ (4) for topaz. Simultaneously, we discussed the possible reasons for the different $K_{0}$ between this study and previous studies. In addition, $T-V$ data fitted by using Fei's thermal expansion equation obtained $\alpha_{300}=1.9(1) \times 10^{-5} \mathrm{~K}^{-1}$ for topaz. Finally, combining with the obtained experimental data in this study with previous results, we plotted the $P-T$ phase diagram of topaz and concluded that under cold subduction conditions. Topaz can carry hydrogen and fluorine elements into the deep upper mantle and further affect the geochemical behavior of the upper mantle. 
Author Contributions: Conceptualization and methodology, D.F. and W.Z.; investigation, J.X. and S.H.; sample source, C.C.; experimental analysis, D.F., W.Z., J.X. and S.H.; writing-original draft preparation, S.H.; writing-review and editing, D.F., W.Z., M.M., S.H., J.X., Z.Y., Y.K., B.L. and W.C.; plotting, S.H.; software, S.H. and J.X. All authors have read and agreed to the published version of the manuscript.

Funding: This project was funded by the National Natural Science Foundation of China (Grant Nos. 41772043, 41802043, and 41674089), the Chinese Academy of Sciences "Light of West China" Program (2017, 2019), the Youth Innovation Promotion Association CAS (Dawei Fan, 2018434), and the Innovation and Entrepreneurship Funding of High-Level Overseas Talents of Guizhou Province (Dawei Fan, [2019] 10).

Acknowledgments: We thank Sergey N. Tkachev, Dongzhou Zhang, Xiaodong Li, and Yanchun Li for the synchrotron XRD experiments assistance. We want to thank two anonymous reviewers for their thoughtful and thorough comments.

Conflicts of Interest: The authors declare no conflict of interest.

\section{References}

1. Ni, H.W.; Zheng, Y.F.; Mao, Z.; Wang, Q.; Chen, R.; Zhang, L. Distribution, cycling and impact of water in the Earth's interior. Natl. Sci. Rev. 2017, 4, 879-891. [CrossRef]

2. Zheng, Y.F.; Chen, R.X.; Xu, Z.; Zhang, S.B. The transport of water in subduction zones. Sci. China Earth Sci. 2016, 59, 651-682. [CrossRef]

3. Bindi, L.; Bendeliani, A.; Bobrov, A.; Matrosova, E.; Irifune, T. Incorporation of $\mathrm{Mg}$ in phase $\mathrm{Egg}_{\mathrm{g}} \mathrm{AlSiO}_{3} \mathrm{OH}$ : Toward a new polymorph of phase $\mathrm{H}, \mathrm{MgSiH}_{2} \mathrm{O}_{4}$, a carrier of water in the deep mantle. Am. Mineral. 2020, 105, 132-135. [CrossRef]

4. Panero, W.R.; Caracas, R. Stability and Solid Solutions of Hydrous Alumino-Silicates in the Earth's Mantle. Minerals 2020, 10, 330. [CrossRef]

5. Zheng, Y.F. Subduction zone geochemistry. Geosci. Front. 2019, 10, 1223-1254. [CrossRef]

6. Piet, H.; Leinenweber, K.D.; Tappan, J.; Greenberg, E.; Prakapenka, V.B.; Buseck, P.R.; Shim, S.H. Dehydration of delta-AlOOH in Earth's Deep Lower Mantle. Minerals 2020, 10, 384. [CrossRef]

7. Nakao, A.; Iwamori, H.; Nakakuki, T. Effects of water transportation on subduction dynamics: Roles of viscosity and density reduction. Earth Planet. Sci. Lett. 2016, 454, 178-191. [CrossRef]

8. Liu, X.C.; Matsukage, K.N.; Nishihara, Y.; Suzuki, T.; Takahashi, E. Stability of the hydrous phases of Al-rich phase D and Al-rich phase $\mathrm{H}$ in deep subducted oceanic crust. Am. Mineral. 2019, 104, 64-72. [CrossRef]

9. Kakizawa, S.; Inoue, T.; Nakano, H.; Kuroda, M.; Sakamoto, N.; Yurimoto, H. Stability of Al-bearing superhydrous phase $\mathrm{B}$ at the mantle transition zone and the uppermost lower mantle. Am. Mineral. 2018, 103, 1221-1227. [CrossRef]

10. Zhang, L.; Smyth, J.R.; Kawazoe, T.; Jacobsen, S.D.; Niu, J.J.; He, X.J.; Qin, S. Stability, composition, and crystal structure of Fe-bearing Phase E in the transition zone. Am. Mineral. 2019, 104, 1620-1624. [CrossRef]

11. Peng, Y.; Mookherjee, M. Thermoelasticity of tremolite amphibole: Geophysical implications. Am. Mineral. 2020, 105, 904-916. [CrossRef]

12. Satta, N.; Marquardt, H.; Kurnosov, A.; Buchen, J.; Kawazoe, T.; McCammon, C.; Ballaran, T.B. Single-crystal elasticity of iron-bearing phase $\mathrm{E}$ and seismic detection of water in Earth's upper mantle. Am. Mineral. 2019, 104, 1526-1529. [CrossRef]

13. Schulze, K.; Pamato, M.G.; Kurnosov, A.; Ballaran, T.B.; Glazyrin, K.; Pakhomova, A.; Marquardt, H. High-pressure single-crystal structural analysis of $\mathrm{AlSiO}_{3} \mathrm{OH}$ phase egg. Am. Mineral. 2018, 103, 1975-1980. [CrossRef]

14. Xu, J.G.; Kuang, Y.Q.; Zhang, B.; Liu, Y.G.; Fan, D.W.; Li, X.D.; Xie, H.S. Thermal equation of state of natural tourmaline at high pressure and temperature. Phys. Chem. Miner. 2016, 43, 315-326. [CrossRef]

15. Xu, J.G.; Zhang, D.Z.; Fan, D.W.; Wu, X.; Shi, F.; Zhou, W.G. Compressional behavior of natural eclogitic zoisite by synchrotron X-ray single-crystal diffraction to 34 GPa. Phys. Chem. Miner. 2019, 46, 333-341. [CrossRef]

16. Yang, C.P.; Inoue, T.; Kikegawa, T. P-V-T equation of state of hydrous phase A up to 10.5 GPa. Am. Mineral. 2020. [CrossRef]

17. Holland, T.J.B.; Redfern, S.A.T.; Pawley, A.R. Volume behavior of hydrous minerals at high pressure and temperature; II, Compressibilities of lawsonite, zoisite, clinozoisite, and epidote. Am. Mineral. 1996, 81, 341-348. [CrossRef] 
18. Wunder, B.; Rubie, D.C.; Ross, C.R.; Medenbach, O.; Seifert, F.; Schreyer, W. Synthesis, stability, and properties of $\mathrm{Al}_{2} \mathrm{SiO}_{4}(\mathrm{OH})_{2}$ : A fully hydrated analog of topaz. Am. Mineral. 1993, 78, 285-297.

19. O'Bannon, E.F.; Williams, Q. A Cr ${ }^{3+}$ luminescence study of natural topaz $\mathrm{Al}_{2} \mathrm{SiO}_{4}(\mathrm{~F}, \mathrm{OH})_{2}$ up to $60 \mathrm{GPa}$. Am. Mineral. 2019, 104, 1656-1662. [CrossRef]

20. Yamamoto, S.; Senshu, H.; Rino, S.; Omori, S.; Maruyama, S. Granite subduction: Arc subduction, tectonic erosion and sediment subduction. Gondwana Res. 2009, 15, 443-453. [CrossRef]

21. Zou, T.R.; Chao, H.Z.; Wu, B.Q. Orogenic and anorogenic granitoids in the altay mountains of xinjiang and their discrimination criteria. Acta Geol. Sinica Engl. Ed. 1989, 2, 45-64. [CrossRef]

22. Wunder, B.; Medenbach, O.; Krause, W.; Schreyer, W. Synthesis, properties and stability of $\mathrm{Al}_{3} \mathrm{Si}_{2} \mathrm{O}_{7}(\mathrm{OH})_{3}$ (Phase $\mathrm{Pi}$ ), a hydrous high-pressure phase in the system $\mathrm{Al}_{2} \mathrm{O}_{3}-\mathrm{SiO}_{2}-\mathrm{H}_{2} \mathrm{O}$ (ASH). Eur. J. Mineral. 1993, 5, 637-649. [CrossRef]

23. Ono, S. High temperature stability limit of phase egg, $\mathrm{AlSiO}_{3}(\mathrm{OH})$. Contrib. Mineral. Petr. 1999, 137, 83-89. [CrossRef]

24. Letnikov, F.A. Topaz granites in northern Kazakhstan. Petrology 2008, 16, 319-334. [CrossRef]

25. Dobrzhinetskaya, L.F.; Green, H.W. Experimental studies of mineralogical assemblages of metasedimentary rocks at Earth's mantle transition zone conditions. J. Metamorph. Geol. 2007, 25, 83-96. [CrossRef]

26. Tennakoon, S.; Peng, Y.; Mookherjee, M.; Speziale, S.; Manthilake, G.; Besara, T.; Andreu, L.; Rivera, F. Single crystal elasticity of natural topaz at high-temperatures. Sci. Rep. UK 2018, 8, 9. [CrossRef]

27. Barton, M.D.; Haselton, H.T.; Hemingway, B.S.; Kleppa, O.J.; Robie, R.A. The thermodynamic properties of fluor-topaz. Am. Mineral. 1982, 67, 350-355.

28. Zhang, R.Y.; Liou, J.G.; Shu, J.F. Hydroxyl-rich topaz in high-pressure and ultrahigh-pressure kyanite quartzites, with retrograde woodhouseite, from the Sulu terrane, eastern China. Am. Mineral. 2002, 87, 445-453. [CrossRef]

29. Alberico, A.; Ferrando, S.; Ivaldi, G.; Ferraris, G. X-ray single-crystal structure refinement of an OH-rich topaz from Sulu UHP terrane (Eastern China)-Structural foundation of the correlation between cell parameters and fluorine content. Eur. J. Mineral. 2003, 15, 875-881. [CrossRef]

30. Gatta, G.D.; Nestola, F.; Ballaran, T.B. Elastic behaviour and structural evolution of topaz at high pressure. Phys. Chem. Miner. 2006, 33, 235-242. [CrossRef]

31. Liu, Y.X.; Qin, S.; Li, H.J.; Li, X.D.; Liu, J. In situ high-pressure X-ray diffraction of natural topaz. Nucl. Sci. Technol. 2008, 31, 497-500.

32. Gatta, G.D.; Morgenroth, W.; Dera, P.; Petitgirard, S.; Liermann, H.P. Elastic behavior and pressure-induced structure evolution of topaz up to 45 GPa. Phys. Chem. Miner. 2014, 41, 569-577. [CrossRef]

33. Komatsu, K.; Kagi, H.; Marshall, W.G.; Kuribayashi, T.; Parise, J.B.; Kudoh, Y. Pressure dependence of the hydrogen-bond geometry in topaz-OD from neutron powder diffraction. Am. Mineral. 2008, 93, 217-227. [CrossRef]

34. Komatsu, K.; Kuribayashi, T.; Kudoh, Y. Effect of temperature and pressure on the crystal structure of topaz, $\mathrm{Al}_{2} \mathrm{SiO}_{4}(\mathrm{OH}, \mathrm{F})_{2}$. J. Miner. Petrol. Sci. 2003, 98, 167-180. [CrossRef]

35. Mookherjee, M.; Tsuchiya, J.; Hariharan, A. Crystal structure, equation of state, and elasticity of hydrous aluminosilicate phase, topaz-OH $\left(\mathrm{Al}_{2} \mathrm{SiO}_{4}(\mathrm{OH})_{2}\right)$ at high pressures. Phys. Earth Planet. Inter. 2016, 251, $24-35$. [CrossRef]

36. Ulian, G.; Valdre, G. Effects of fluorine content on the elastic behavior of topaz $\left[\mathrm{Al}_{2} \mathrm{SiO}_{4}(\mathrm{~F}, \mathrm{OH})_{2}\right]$. Am. Mineral. 2017, 102, 347-356. [CrossRef]

37. Haussuhl, S. Thermoelastic properties of beryl, topaz, diaspore, sanidine and periclase. Z. Kristallogr. 1993, 204, 67-76. [CrossRef]

38. Komatsu, K.; Kagi, H.; Okada, T.; Kuribayashi, T.; Parise, J.B.; Kudoh, Y. Pressure dependence of the $\mathrm{OH}$-stretching mode in F-rich natural topaz and topaz-OH. Am. Mineral. 2005, 90, 266-270. [CrossRef]

39. Fei, Y.W.; Ricolleau, A.; Frank, M.; Mibe, K.; Shen, G.Y.; Prakapenka, V. Toward an internally consistent pressure scale. Proc. Natl. Acad. Sci. USA 2007, 104, 9182-9186. [CrossRef]

40. Rivers, M.; Prakapenka, V.B.; Kubo, A.; Pullins, C.; Holl, C.M.; Jacobsen, S.D. The COMPRES/GSECARS gas-loading system for diamond anvil cells at the Advanced Photon Source. High Press. Res. 2008, 28, 273-292. [CrossRef] 
41. Dera, P.; Zhuravlev, K.; Prakapenka, V.; Rivers, M.L.; Finkelstein, G.J.; Grubor-Urosevic, O.; Tschauner, O.; Clark, S.M.; Downs, R.T. High pressure single-crystal micro X-ray diffraction analysis with GSE_ADA/RSV software. High Press. Res. 2013, 33, 466-484. [CrossRef]

42. Kantor, I.; Prakapenka, V.; Kantor, A.; Dera, P.; Kurnosov, A.; Sinogeikin, S.; Dubrovinskaia, N.; Dubrovinsky, L. BX90: A new diamond anvil cell design for X-ray diffraction and optical measurements. Rev. Sci. Instrum. 2012, 83, 6. [CrossRef] [PubMed]

43. Fan, D.W.; Fu, S.Y.; Yang, J.; Tkachev, S.N.; Prakapenka, V.B.; Lin, J.F. Elasticity of single-crystal periclase at high pressure and temperature: The effect of iron on the elasticity and seismic parameters of ferropericlase in the lower mantle. Am. Mineral. 2019, 104, 262-275. [CrossRef]

44. Mao, H.K.; Xu, J.; Bell, P.M. Calibration of the ruby pressure gauge to 800 kbar under quasi-hydrostatic conditions. J. Geophys. Res. Solid Earth Planet. 1986, 91, 4673-4676. [CrossRef]

45. Zhang, D.Z.; Dera, P.K.; Eng, P.J.; Stubbs, J.E.; Zhang, J.S.; Prakapenka, V.B.; Rivers, M.L. High pressure single crystal diffraction at $\mathrm{PX}^{\wedge} 2$. Jove J. Vis. Exp. 2017. [CrossRef]

46. Fan, D.W.; Zhou, W.G.; Wei, S.Y.; Liu, Y.G.; Ma, M.N.; Xie, H.S. A simple external resistance heating diamond anvil cell and its application for synchrotron radiation X-Ray diffraction. Rev. Sci. Instrum. 2010, 81, 5. [CrossRef] [PubMed]

47. Hammersley, A.P.; Svensson, S.O.; Hanfland, M.; Fitch, A.N.; Hausermann, D. Two-dimensional detector software: From real detector to idealised image or two-theta scan. High Pressure Res. 1996, 14, 235-248. [CrossRef]

48. Toby, B.H. EXPGUI, a graphical user interface for GSAS. J. Appl. Crystallogr. 2001, 34, 210-213. [CrossRef]

49. Toby, B.H.; Von Dreele, R.B.; Larson, A.C. CIF applications. XIV. Reporting of Rietveld results using pdCIF: GSAS2CIF. J. Appl. Crystallogr. 2003, 36, 1290-1294. [CrossRef]

50. Le Bail, A.; Duroy, H.; Fourquet, J.L. Ab-initio structure determination of $\mathrm{LiSbWO}_{6}$ by X-ray-powder diffraction. Mater. Res. Bull. 1988, 23, 447-452. [CrossRef]

51. Angel, R.J.; Gonzalez-Platas, J.; Alvaro, M. EosFit7c and a Fortran module (library) for equation of state calculations. Z. Krist. Cryst. Mater. 2014, 229. [CrossRef]

52. Angel, R.J. Equations of State. Rev. Mineral. Geochem. 2000, 41, 35-59. [CrossRef]

53. Gauzzi, T.; Graca, L.M.; Lagoeiro, L.; Mendes, I.D.; Queiroga, G.N. The fingerprint of imperial topaz from Ouro Preto region (Minas Gerais state, Brazil) based on cathodoluminescence properties and composition. Mineral. Mag. 2018, 82, 943-960. [CrossRef]

54. Agangi, A.; Gucsik, A.; Nishido, H.; Ninagawa, K.; Kamenetsky, V.S. Relation between cathodoluminescence and trace-element distribution of magmatic topaz from the Ary-Bulak massif, Russia. Mineral. Mag. 2018, 80, 881-899. [CrossRef]

55. Gatta, G.D.; Merlini, M.; Lee, Y.; Poli, S. Behavior of epidote at high pressure and high temperature: A powder diffraction study up to 10 GPa and 1,200 K. Phys. Chem. Miner. 2011, 38, 419-428. [CrossRef]

56. Angel, R.J.; Bujak, M.; Zhao, J.; Gatta, G.D.; Jacobsen, S.D. Effective hydrostatic limits of pressure media for high-pressure crystallographic studies. J. Appl. Crystallogr. 2007, 40, 26-32. [CrossRef]

57. Klotz, S.; Chervin, J.C.; Munsch, P.; Le Marchand, G. Hydrostatic limits of 11 pressure transmitting media. J. Phys. D Appl. Phys. 2009, 42, 7. [CrossRef]

58. Pawley, A.R. The pressure and temperature stability limits of lawsonite-implications for $\mathrm{H}_{2} \mathrm{O}$ recycling in subduction zones. Contrib. Mineral. Petr. 1994, 118, 99-108. [CrossRef]

59. Pollack, H.N.; Chapman, D.S. Regional Variation of Heat-Flow, Geotherms, and Lithospheric Thickness. Tectonophysics 1977, 38, 279-296. [CrossRef]

60. Zang, S.X.; Liu, Y.G.; Ning, J.Y. Thermal structure of the lithosphere in North China. Chin. J Geophys. 2002, 45, 56-66. [CrossRef]

61. Artemieva, I.M.; Mooney, W.D. Thermal thickness and evolution of Precambrian lithosphere: A global study. J. Geophys. Res. Solid Earth 2001, 106, 16387-16414. [CrossRef]

62. Bina, C.R.; Navrotsky, A. Possible presence of high-pressure ice in cold subducting slabs. Nature 2000, 408, 844-847. [CrossRef] [PubMed]

63. Domanik, K.J.; Holloway, J.R. The stability and composition of phengitic muscovite and associated phases from 5.5 to 11 GPa: Implications for deeply subducted sediments. Geochim. Cosmochim. Acta 1996, 60, 4133-4150. [CrossRef] 
64. Koch-Muller, M.; Matsyuk, S.S.; Rhede, D.; Wirth, R.; Khisina, N. Hydroxyl in mantle olivine xenocrysts from the Udachnaya kimberlite pipe. Phys. Chem. Miner. 2006, 33, 276-287. [CrossRef]

65. Bell, D.R.; Rossman, G.R.; Moore, R.O. Abundance and partitioning of $\mathrm{OH}$ in a high-pressure magmatic system: Megacrysts from the Monastery kimberlite, South Africa. J. Petrol. 2004, 45, 1539-1564. [CrossRef]

66. Katayama, I.; Nakashima, S.; Yurimoto, H. Water content in natural eclogite and implication for water transport into the deep upper mantle. Lithos 2006, 86, 245-259. [CrossRef]

67. Grutzner, T.; Klemme, S.; Rohrbach, A.; Gervasoni, F.; Berndt, J. The effect of fluorine on the stability of wadsleyite: Implications for the nature and depths of the transition zone in the Earth's mantle. Earth Planet Sci. Lett. 2018, 482, 236-244. [CrossRef]

(C) 2020 by the authors. Licensee MDPI, Basel, Switzerland. This article is an open access article distributed under the terms and conditions of the Creative Commons Attribution (CC BY) license (http://creativecommons.org/licenses/by/4.0/). 